Revista Eletrônica de Direito Processual - REDP. Volume 16. Julho a dezembro de 2015

Periódico Semestral da Pós-Graduação Stricto Sensu em Direito Processual da UERJ

Patrono: José Carlos Barbosa Moreira. ISSN 1982-7636. pp. 605-639 http://www.e-publicacoes.uerj.br/index.php/redp/index

\title{
LIQUIDAÇÃO DE SENTENÇA: BREVE ENSAIO A PARTIR DO CPC/151_2
}

\section{CONDEMNATION'S AMOUNT SETTLEMENT: BRIEF ESSAY BASED ON THE CODE OF CIVIL PROCEDURE OF 2015}

Rodrigo Mazzei

Pós-doutorado (UFES - bolsa CAPES-REUNI), Doutor (FADISP) e Mestre (PUC/SP).

Professor (graduação e do mestrado) da Universidade Federal do Espírito Santo (UFES). Vice-presidente do Instituto dos Advogados do Estado do Espírito Santo (IAEES). Presidente da Escola Superior da Advocacia (ESA-OAB/ES). rmazzei@superig.com.br

RESUMO: Busca-se por este ensaio fazer uma abordagem geral da disciplina da liquidação de sentença, com as principais mudanças trazidas pelo novo código de processo civil.

PALAVRAS-CHAVE: Liquidação de sentença; Novo Código de Processo Civil; Liquidação por arbitramento; Liquidação por artigos; Condenação genérica.

\footnotetext{
${ }^{1}$ Artigo recebido em 13/07/2015 e aprovado em 04/11/2015.

${ }^{2} \mathrm{O}$ presente texto faz parte de uma sequência de trabalhos que efetuamos acerca do tema liquidação de sentença, iniciados no ano de 2006. No sentido, confira-se (entre outros trabalhos que tratam sobre o assunto): A liquidação por arbitramento sob ótica das Leis 11.232/05 e 11.382/06. Revista Eletrônica de Direito Processual, Volume V, p. 484-516, 2010; A liquidação por arbitramento e a liquidação por artigos. Revista Forense, v. 395, p. 225-250, 2008; A 'liquidação' por cálculos após as (últimas) reformas (Leis 11.232/05 e 11.382/06). In: Ernane Fidélis dos Santos; Luiz Rodrigues Wambier; Nelson Nery Jr.; Teresa Arruda Alvim Wambier. (Org.). Execução civil: estudos em homenagem ao Professor Humberto Theodoro Jr.. São Paulo: Revista dos Tribunais, 2007, p. 551-562; Título executivo, liquidação de sentença e coisa julgada no mandado de injunção: análise a partir dos precedentes do Supremo Tribunal Federal. In: Fredie Didier Jr.. (Org.). Execução civil: estudos em homenagem ao professor Paulo Furtado. Rio de Janeiro: Lumen Juris, 2006, p. 279-316; Reforma do CPC. São Paulo: Revista dos Tribunais, 2006, p. 147-198. Em coautoria com o professor Tiago Figueiredo Gonçalves, produzimos ainda os seguintes textos: Linhas básicas acerca da liquidação de sentença coletiva. Revista Brasileira de Direito Processual (RBDPro), v. 87, p. 70-95, 2014; Liquidação de sentença (individual e coletiva): seus aspectos nucleares no processo comum e do trabalho. Revista Eletrônica - Tribunal Regional do Trabalho do Paraná, v. 3, p. 103-129, 2014
} 
Revista Eletrônica de Direito Processual - REDP. Volume 16. Julho a dezembro de 2015

Periódico Semestral da Pós-Graduação Stricto Sensu em Direito Processual da UERJ

Patrono: José Carlos Barbosa Moreira. ISSN 1982-7636. pp. 605-639 http://www.e-publicacoes.uerj.br/index.php/redp/index

ABSTRACT: This essay aims to make a general approach about the discipline of the procedural phase of Condemnation's amount settlement, with the main changes brought by New Code of Civil Procedure.

KEYWORDS: Condemnation's amount settlement. New Code of Civil Procedure. Settlement by arbitration. Settlement by articles. Generic condemnation.

SUMÁRIO: Introdução; 1. Espécies de Liquidação; 1.1-Liquidação por arbitramento (art. 509, I); 1.1.1-Impossibilidade de determinação de ofício; 1.1.2-Aplicação das regras de perícia; 1.1.3-Nomeação de perito como atividade supletiva à fase vestibular (art. 472); 1.1.4-Pareceres e/ou documentos elucidativos; 1.1.5-Procedimento em resenha; 1.1.6Honorários de advogado; 1.2-Liquidação por artigos (art. 509, II); 1.2.1-Natureza jurídica; 1.2.2 - Petição; 1.2.3-Intimação (citação) na pessoa do advogado; 1.2 .4 - Decisão; 1.2.5Honorários; 1.3-Apuração por simples cálculo; 2-Liquidação de sentença nos casos de obrigação de fazer, não fazer e de entrega de coisa; 3-Manutenção da impossibilidade de liquidação de título executivo extrajudicial; 4-Liquidação de sentença no âmbito do processo trabalhista; 5- Liquidação no processo coletivo; 6-Legitimidade; 6.1-Limitação de litisconsórcio em liquidação de sentença; 7- Possibilidade da liquidação de sentença e cumprimento de sentença simultâneo; 8- Princípio da fidelidade e a Súmula 344 do STJ; 8.1 Capítulos decisórios implícitos; 9- Alegação de fatos impeditivos, modificativos ou extintivos; 10 - Recurso cabível; 11 - Liquidação na pendência do julgamento do recurso; 11.1 - Liquidação na pendência do julgamento do recurso não se confunde com 'execução provisória' (cumprimento provisório de sentença); 11.2- Decisão com capítulos líquidos e ilíquidos; 11.3- Peças que devem instruir a liquidação provisória; 11.4- Conjugação com a hipoteca judiciária; 12- Quadro Comparativo.

\section{Introdução.}

O objetivo do presente texto é efetuar um passeio horizontal sobre o perfil e desdobramentos principais da liquidação de sentença, fixando-se na abordagem o Código de Processo Civil de 2015 como a bússola de análise. Assim, sem pretensão de apresentar um agudo texto sobre o instituto, nos parece correto afirmar, logo de partida, que a expressão 
Revista Eletrônica de Direito Processual - REDP. Volume 16. Julho a dezembro de 2015

Periódico Semestral da Pós-Graduação Stricto Sensu em Direito Processual da UERJ

Patrono: José Carlos Barbosa Moreira. ISSN 1982-7636. pp. 605-639 http://www.e-publicacoes.uerj.br/index.php/redp/index

"liquidação de sentença" designa o procedimento ou a atividade cognitiva voltada a conferir liquidez ou determinação à obrigação declarada e reconhecida em anterior decisão condenatória genérica, tornando o título executivo apto à formulação de tutela jurisdicional executiva.

Importante notar que o atributo da (i)liquidez ou da (in)determinação se relaciona à obrigação, logo é sobre ela - obrigação - que recai a atividade de liquidação. A decisão que certifica a obrigação indeterminada não é objeto de liquidação, e tão somente possibilita a abertura da via na qual a atividade de liquidação vai ser realizada.

O novo Código de Processo Civil trabalha com a ideia de que as sentenças (= decisões judiciais) devem ser proferidas, sempre que possível, de forma líquida. Basta observar o desenho do art. $491^{3}$, em que há previsão de que as decisões proferidas nas ações relativas à obrigação de pagar quantia, ainda que formulado pedido genérico, deverão definir a extensão da obrigação, o índice de correção monetária, a taxa de juros, o termo inicial de ambos e a periodicidade da capitalização dos juros.

Não obstante tal linha, há situações não acobertadas pelo art. 491 e, por tal passo, as decisões judiciais acabarão sendo proferidas sem preencher o predicado da liquidez. Assim, a liquidação de sentença assume caráter residual, pois o CPC/15 adota nítida postura de que as decisões proferidas nas ações relativas à obrigação de pagar quantia devem ser proferidas de forma líquida, devendo a remessa ser feita para liquidação apenas se não for possível que se confeccione sentença líquida, na moldagem do art. 491 do CPC/15.

Como já anunciado, tenciona-se apresentar a seguir abordagem inicial a respeito do procedimento de liquidação de sentença e as principais mudanças trazidas pelo Código de Processo Civil de 2015, não sendo o presente trabalho exaustivo, muito menos agudo em

\footnotetext{
${ }^{3}$ Art. 491. Na ação relativa à obrigação de pagar quantia, ainda que formulado pedido genérico, a decisão definirá desde logo a extensão da obrigação, o índice de correção monetária, a taxa de juros, o termo inicial de ambos e a periodicidade da capitalização dos juros, se for o caso, salvo quando: I - não for possível determinar, de modo definitivo, o montante devido; II - a apuração do valor devido depender da produção de prova de realização demorada ou excessivamente dispendiosa, assim reconhecida na sentença. § $1^{\circ}$ Nos casos previstos neste artigo, seguir-se-á a apuração do valor devido por liquidação. $2^{\circ} \mathrm{O}$ disposto no caput também se aplica quando o acórdão alterar a sentença.
} 
Revista Eletrônica de Direito Processual - REDP. Volume 16. Julho a dezembro de 2015

Periódico Semestral da Pós-Graduação Stricto Sensu em Direito Processual da UERJ

Patrono: José Carlos Barbosa Moreira. ISSN 1982-7636. pp. 605-639 http://www.e-publicacoes.uerj.br/index.php/redp/index

todos os pontos que o debate merece atenção. O objetivo do ensaio é apresentar, repita-se, uma visão panorâmica, com a exposição dos pontos de maior destaque.

\section{Espécies de Liquidação}

O CPC/15 - em seu art. $509^{4}$ - indica a existência de duas espécies de liquidação (a) liquidação por arbitramento (inciso I) e (b) liquidação por artigos (inciso II), excluindo corretamente a liquidação por cálculos (antes regulada pelo revogado art. 475-B do $\mathrm{CPC} / 73) .^{5}$

A postura afigura-se correta porque a elaboração dos cálculos já tem como pressuposto a existência de decisão líquida ou determinada, cujo valor nela estabelecido é submetido a simples operação aritmética objetivando torná-lo atual ao momento da execução ${ }^{6}$ Não há, pois, tecnicamente a liquidação da obrigação, mas exercício de atualização no tempo. Assim, nos termos do $\S 2^{\circ}$ do art. 509, quando a apuração do valor depender apenas de cálculo aritmético, o credor poderá promover, desde logo, o cumprimento da sentença, usando programa de atualização financeira a ser disponibilizado pelo Conselho Nacional de Justiça ( $\left(3^{\circ}\right.$ do art. 509).

\section{1-Liquidação por arbitramento (art. 509, I).}

\footnotetext{
${ }^{4}$ Art. 509. Quando a sentença condenar ao pagamento de quantia ilíquida, proceder-se-á à sua liquidação, a requerimento do credor ou do devedor: I - por arbitramento, quando determinado pela sentença, convencionado pelas partes ou exigido pela natureza do objeto da liquidação; II - pelo procedimento comum, quando houver necessidade de alegar e provar fato novo. $\S 1^{\circ}$ Quando na sentença houver uma parte líquida e outra ilíquida, ao credor é lícito promover simultaneamente a execução daquela e, em autos apartados, a liquidação desta. $\S$ $2^{\circ}$ Quando a apuração do valor depender apenas de cálculo aritmético, o credor poderá promover, desde logo, o cumprimento da sentença. $\S 3^{\circ} \mathrm{O}$ Conselho Nacional de Justiça desenvolverá e colocará à disposição dos interessados programa de atualização financeira. $\S 4^{\circ} \mathrm{Na}$ liquidação é vedado discutir de novo a lide ou modificar a sentença que a julgou.

${ }^{5}$ No tema: MAZZEI, Rodrigo. A 'liquidação’ por cálculos após as (últimas) reformas (Leis 11.232/05e 11.382/06). In: Ernane Fidélis dos Santos; Luiz Rodrigues Wambier; Nelson Nery Jr.; Teresa Arruda Alvim Wambier. (Org.). Execução civil: estudos em homenagem ao Professor Humberto Theodoro Jr.. São Paulo: Revista dos Tribunais, 2007

${ }^{6}$ MAZZEI, Rodrigo. Reforma do CPC. São Paulo: Revista dos Tribunais, 2006, p. 167-168;
} 
Revista Eletrônica de Direito Processual - REDP. Volume 16. Julho a dezembro de 2015

Periódico Semestral da Pós-Graduação Stricto Sensu em Direito Processual da UERJ

Patrono: José Carlos Barbosa Moreira. ISSN 1982-7636. pp. 605-639 http://www.e-publicacoes.uerj.br/index.php/redp/index

As hipóteses de permissão da liquidação por arbitramento estão enumeradas no art. 509, I, tendo espaço se determinada pela sentença, for objeto de convenção das partes ou exigida pela natureza do objeto da liquidação.

É a que acontece mediante a realização de prova pericial, em qualquer das modalidades

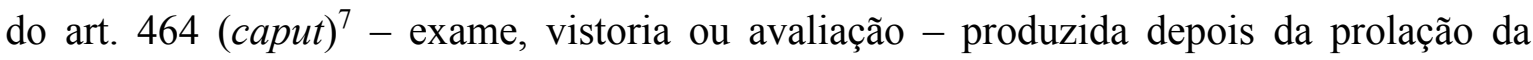
sentença. Tal espécie de liquidação é utilizada em casos nos quais ordinariamente seria possível que a determinação da condenação fosse efetuada antes da prolação da sentença. No entanto, tal não ocorre em razão de ser mais viável que se profira a sentença desde logo e se postergue a determinação da condenação, colhendo-se prova futura, de natureza pericial. Isso porque a matéria que envolve a perícia futura já se encontra resolvida, estando seus parâmetros fixados, mas a definição dos limites da condenação depende de prova técnica. Um exemplo de situação que pode dar ensejo à liquidação por arbitramento está no disposto no art. 14 da Lei 4.717/65 (Lei da Ação Popular), que admite que a apuração do valor da lesão - já atestada na sentença - seja realizada posteriormente, caso dependa de prova técnica (“avaliação ou perícia”). ${ }^{8}$

Percebe-se que na liquidação por arbitramento há uma remessa proposital de prova de natureza técnica para outra fase processual, que, a priori, poderia ter sido ultimada antes da sentença, haja vista que para a sua consecução os dados poderiam ali ser colhidos, ainda que com a juntada de elementos de apoio. Não se faz no requerimento da liquidação por arbitramento postulação (para a prova) de "fato novo", pois o "fato", além de já estar provado, recebeu deliberação sentencial em toda a sua extensão, faltando apenas prova eminentemente técnica para o seu fechamento. Há diferença no material cognitivo das liquidações, na medida em que a por arbitramento é guiada por elementos já constantes nos autos, ao passo que, diferentemente, se o ambiente processual tiver sido instaurado por liquidação por artigos, há o alargamento na prova a ser colhida para a determinação do título, aferindo-se fatos novos.

Numa resenha apertada, pode se dizer que a liquidação por arbitramento é utilizada em casos nos quais ordinariamente seria possível efetuar a determinação da condenação antes

\footnotetext{
${ }^{7}$ Art. 464. A prova pericial consiste em exame, vistoria ou avaliação.

${ }^{8}$ Art. 14 Se o valor da lesão ficar provado no curso da causa, será indicado na sentença; se depender de avaliação ou perícia, será apurado na execução.
} 
Revista Eletrônica de Direito Processual - REDP. Volume 16. Julho a dezembro de 2015

Periódico Semestral da Pós-Graduação Stricto Sensu em Direito Processual da UERJ

Patrono: José Carlos Barbosa Moreira. ISSN 1982-7636. pp. 605-639 http://www.e-publicacoes.uerj.br/index.php/redp/index

da prolação da sentença. No entanto, tal não ocorre em razão de ser mais viável que se profira a sentença desde logo e se postergue a determinação da condenação, colhendo-se prova futura, de natureza pericial. Isso porque a matéria que envolve a perícia futura já se encontra resolvida, estando seus parâmetros fixados, mas a definição dos limites da condenação depende de prova técnica. Dentre os motivos para que a perícia de determinação da condenação fique diferida para momento futuro, podemos destacar o encadeamento progressivo dos atos processuais. Ora, se existem elementos para se julgar procedente o pedido indenizatório, em alguns casos é preferível que se decida logo sobre a questão (alcançando o an debeatur), postergando-se seu aperfeiçoamento para outra fase (ou seja, a fixação do quantum debeatur).

É de bom tom lembrar que o art. 509, I, permite a liquidação de sentença por convenção efetuada entre as partes. Muito embora tal possibilidade já estivesse traçada no CPC/73, cremos que o $\mathrm{CPC} / 15$ poderá dar novo colorido ao regramento, fazendo-se tal convenção a partir dos negócios jurídicos processuais, previsto de forma expressa no art. 190 da nova codificação processual ${ }^{9}$. Como é curial, em sede de negócio jurídico processual é permitido que as partes plenamente capazes possam efetuar mudanças procedimentais em questões que admitam a autocomposição, assim como convencionar sobre ônus, poderes, faculdades e deveres processuais, antes ou durante o processo. ${ }^{10}$

A regra disciplinada no art. 510 do $\mathrm{CPC} / 15^{11}$ apresenta diferenças em sua estrutura redacional, quando se tem em vista o que era previsto no artigo correspondente no CPC/73 $(\text { art. } 475-D)^{12}$. Por seu enunciado, o juiz não nomeará perito imediatamente após o

\footnotetext{
${ }^{9}$ Art. 190. Versando o processo sobre direitos que admitam autocomposição, é lícito às partes plenamente capazes estipular mudanças no procedimento para ajustá-lo às especificidades da causa e convencionar sobre os seus ônus, poderes, faculdades e deveres processuais, antes ou durante o processo. Parágrafo único. De ofício ou a requerimento, o juiz controlará a validade das convenções previstas neste artigo, recusando-lhes aplicação somente nos casos de nulidade ou de inserção abusiva em contrato de adesão ou em que alguma parte se encontre em manifesta situação de vulnerabilidade.

${ }^{10}$ Acerca dos negócios jurídicos processuais, confira-se: MAZZEI, Rodrigo; CHAGAS, Barbara. Breve diálogo entre os negócios jurídicos processuais e a arbitragem. Revista de Processo (REpro), v. 237, p. 223236, 2014.

${ }^{11}$ Art. 510. Na liquidação por arbitramento, o juiz intimará as partes para a apresentação de pareceres ou documentos elucidativos, no prazo que fixar, e, caso não possa decidir de plano, nomeará perito, observandose, no que couber, o procedimento da prova pericial.

${ }^{12}$ Art. 475-D. Requerida a liquidação por arbitramento, o juiz nomeará o perito e fixará o prazo para a entrega do laudo. Parágrafo único. Apresentado o laudo, sobre o qual poderão as partes manifestar-se no prazo de dez dias, o juiz proferirá decisão ou designará, se necessário, audiência.
} 
Revista Eletrônica de Direito Processual - REDP. Volume 16. Julho a dezembro de 2015

Periódico Semestral da Pós-Graduação Stricto Sensu em Direito Processual da UERJ

Patrono: José Carlos Barbosa Moreira. ISSN 1982-7636. pp. 605-639 http://www.e-publicacoes.uerj.br/index.php/redp/index

requerimento da liquidação por arbitramento. Antes disso, intimará as partes para a apresentação de pareceres ou documentos elucidativos a fim de que possa decidir sobre tal. Somente não sendo isto possível, é que seguirá na nomeação do perito.

\subsection{1-Impossibilidade de determinação de ofício.}

Embora o art. 510 permita a falsa impressão de que a liquidação por arbitramento possa ser iniciada de ofício, já que sua redação informa que o “juiz intimará as partes” - como se em atividade de impulso oficial - tal interpretação deve ser bloqueada. Isso porque o art. 510 não pode ser lido desapegado do art. 509 que, por sua vez, é peremptório ao apontar que a liquidação de sentença demanda requerimento da parte interessada, situação que esvazia a possibilidade de início propriamente dito da liquidação pelo juiz.

O que se admite, e nisso não há embaraço algum, é a intimação das partes, através de dicção judicante, para que se dê início à liquidação de sentença por arbitramento. Nesse caso, em atendimento à intimação, o interessado apresentará requerimento com formatação adequada para tanto (que inclui a quesitação). Há, pois, sutil, mas relevante diferença nas duas posturas do juiz, na forma acima exposta, em relação ao início da liquidação de sentença, pois na segunda hipótese o impulso oficial não está na instauração da própria liquidação, mas de convocação para o interessado, dentro de suas faculdades processuais, assim o faça.

\subsection{2-Aplicação das regras de perícia.}

A liquidação por arbitramento, acaso não possa ser decidida de plano pelo juiz após a apresentação de pareceres e documentos elucidativos, está vinculada à nomeação de expert, sendo, portanto, necessária a sua vinculação à prova pericial, com a absorção de suas regras e procedimentos, consoante se infere da parte final do art. 510. Com tal bússola, o ato judicial de recepção da liquidação por arbitramento procederá ao controle do requerimento, devendo indeferir a prova técnica (ainda que parcialmente) naquilo que não for pertinente (art. $470^{13}$ ).

\footnotetext{
13 Art. 470. Incumbe ao juiz: I - indeferir quesitos impertinentes; II - formular os quesitos que entender necessários ao esclarecimento da causa.
} 
Revista Eletrônica de Direito Processual - REDP. Volume 16. Julho a dezembro de 2015

Periódico Semestral da Pós-Graduação Stricto Sensu em Direito Processual da UERJ

Patrono: José Carlos Barbosa Moreira. ISSN 1982-7636. pp. 605-639 http://www.e-publicacoes.uerj.br/index.php/redp/index

\subsection{3-Nomeação de perito como atividade supletiva à fase vestibular}

Inovando em relação à codificação revogada, o CPC/15 determina que o juiz, na abertura da liquidação por arbitramento, intime as partes para apresentação de pareceres ou documentos elucidativos, em prazo a ser fixado no despacho.

Trata-se, pois, de recepção com grande prestígio do disposto no art. $472^{14}$ na liquidação por arbitramento, a fim de permitir a juntada de pareceres ou documentos elucidativos para decidir a questão sem dilação probatória com expert judicial. Assim, somente será nomeado perito, pela letra da lei, após avançada tal fase sem êxito (seja pela não juntada de pareceres ou documentos, seja pela anexação de pareceres ou documentos não elucidativos), sendo, assim, tal procedimento supletivo à providência disposta no art. 472 .

\subsection{4-Pareceres e/ou documentos elucidativos.}

Deve se entender como parecer ou documento elucidativo o material técnico produzido que seja capaz de substituir satisfatoriamente a prova pericial, ou seja, quando sobre as questões de fato que necessitam de exame técnico sejam colacionados material desta qualidade, em restrito respeito ao art. 472. Dessa forma, diante da possibilidade de ocupar o espaço de laudo pericial, o parecer ou documento elucidativo deve estar afinado ao máximo (ainda que com adaptações) aos requisitos vinculados ao laudo pericial, consoante disposto no art. $473^{15}$.

\footnotetext{
${ }^{14}$ Art. 472. O juiz poderá dispensar prova pericial quando as partes, na inicial e na contestação, apresentarem, sobre as questões de fato, pareceres técnicos ou documentos elucidativos que considerar suficientes.

${ }^{15}$ Art. 473. O laudo pericial deverá conter: I - a exposição do objeto da perícia; II - a análise técnica ou científica realizada pelo perito; III - a indicação do método utilizado, esclarecendo-o e demonstrando ser predominantemente aceito pelos especialistas da área do conhecimento da qual se originou; IV - resposta conclusiva a todos os quesitos apresentados pelo juiz, pelas partes e pelo órgão do Ministério Público. $\S 1^{\circ}$ No laudo, o perito deve apresentar sua fundamentação em linguagem simples e com coerência lógica, indicando como alcançou suas conclusões. $\S 2^{\circ}$ É vedado ao perito ultrapassar os limites de sua designação, bem como emitir opiniões pessoais que excedam o exame técnico ou científico do objeto da perícia. $\S 3^{\circ}$ Para o desempenho de sua função, o perito e os assistentes técnicos podem valer-se de todos os meios necessários, ouvindo testemunhas, obtendo informações, solicitando documentos que estejam em poder da parte, de terceiros ou em repartições públicas, bem como instruir o laudo com planilhas, mapas, plantas, desenhos, fotografias ou outros elementos necessários ao esclarecimento do objeto da perícia.
} 
Revista Eletrônica de Direito Processual - REDP. Volume 16. Julho a dezembro de 2015

Periódico Semestral da Pós-Graduação Stricto Sensu em Direito Processual da UERJ

Patrono: José Carlos Barbosa Moreira. ISSN 1982-7636. pp. 605-639 http://www.e-publicacoes.uerj.br/index.php/redp/index

\subsection{5-Procedimento em resenha.}

A parte interessada apresentará a postulação de liquidação por arbitramento, indicando o fato (vinculado à obrigação ilíquida) que necessita de elucidação técnica para a sua quantificação (valor devido). Deve trazer também na mesma peça a quesitação desejada, com a indicação dos pontos capitais que a prova pericial deve desvendar.

Em razão da mudança procedimental levada a cabo, a parte que requerer a liquidação, em homenagem à boa-fé processual, deve trazer no requerimento, desde logo, os pareceres ou documentos elucidativos que possui, intimando-se a contraparte para se manifestar sobre o requerimento e o material técnico probante que eventualmente tenha sido acostado. O juiz fixará o prazo para tanto, e, caso assim não o faça, deve se entender como de cinco dias (art. $\left.218, \S 3^{\mathrm{ol}}\right)$.

A manifestação da contraparte deve ser simétrica à apresentada pelo requerente da liquidação, trazendo, inclusive, quesitação. Caso sejam apresentados pela parte intimada pareceres ou documentos elucidativos, abre-se contraditório para o requerente da liquidação, decidindo o juiz em sequência se na hipótese há material técnico que elucide as questões de fato que reclamavam análise de expert. Caso positivo, decidirá a liquidação, usando como fundamento a prova técnica (parecer e/ou documentação) eleita como adequada. Em situação diversa, através de decisão fundamentada, o juiz descartará os pareceres ou documentos técnicos trazidos até então e nomeará perito, facultando às partes a indicação de assistentes técnicos e, se for o caso, a retificação (justificada) da quesitação já constante de suas respectivas manifestações anteriores.

\subsection{6-Honorários de advogado.}

\footnotetext{
${ }^{16}$ Art. 218. Os atos processuais serão realizados nos prazos prescritos em lei. (...)§ $3^{\circ}$ Inexistindo preceito legal ou prazo determinado pelo juiz, será de 5 (cinco) dias o prazo para a prática de ato processual a cargo da parte.
} 
Revista Eletrônica de Direito Processual - REDP. Volume 16. Julho a dezembro de 2015

Periódico Semestral da Pós-Graduação Stricto Sensu em Direito Processual da UERJ

Patrono: José Carlos Barbosa Moreira. ISSN 1982-7636. pp. 605-639 http://www.e-publicacoes.uerj.br/index.php/redp/index

$\mathrm{O} \S 1^{\circ}$ do art. $85^{17}$ não previu expressamente a fixação de honorários em sede de liquidação de sentença, fazendo alusão apenas à reconvenção, ao cumprimento de sentença (provisório ou definitivo), à execução (resistida ou não), e aos recursos interpostos.

O perfil atual da liquidação por arbitramento, que é medida antecedente ao cumprimento de sentença, parece não mais comportar a fixação de honorários, muito embora no regime anterior seja possível encontrar posição jurisprudencial que entendia em contrário, ou seja, de cabimento de honorários de advogado se esta assumir caráter contencioso ${ }^{18}$. Há, contudo, jurisprudência em sentido inverso ${ }^{19}$, cujo entendimento pode ficar reforçado a partir da não previsão na imposição de honorários cumulativos na liquidação no $\S 1^{\circ}$ do $\operatorname{art} .85$, do $\mathrm{CPC} / 15$.

\section{2-Liquidação por artigos (art. 509, II).}

Destaque-se, de plano, que o $\mathrm{CPC} / 15$ não utiliza expressamente a nomenclatura liquidação por artigos, limitando-se a indicar que a liquidação seguirá "pelo procedimento comum", quando houver necessidade de alegar e provar fato novo (características da liquidação por artigos).

Em comparação com o revogado Código, não há artigo correspondente exato no $\mathrm{CPC} / 73$, apenas o disposto no art. $475-\mathrm{F}^{20}$, bem mais genérico do que o atual 508 .

De forma bem resumida, pode se dizer que a liquidação por artigos é aquela que se realiza quando exigida a aferição de fato novo (fato secundário e dependente do que já foi decidido), reclamando, por isso, dados muito acima dos já obtidos até então. Havendo

\footnotetext{
${ }^{17}$ Art. 85. A sentença condenará o vencido a pagar honorários ao advogado do vencedor. $\S 1^{\circ}$ São devidos honorários advocatícios na reconvenção, no cumprimento de sentença, provisório ou definitivo, na execução, resistida ou não, e nos recursos interpostos, cumulativamente.

${ }^{18}$ No sentido: "Esta Corte tem entendido, uma vez estabelecida a resistência da parte ré na liquidação de sentença por arbitramento, devida a estipulação de honorários advocatícios, nos termos do art. 20, $\S 4^{\circ}$, do CPC. II” (STJ, AgRg no AREsp 532.835/RS).

${ }^{19}$ No sentido: "Os honorários advocatícios como parcela autônoma em processo de liquidação de sentença não é cabível, sob pena de incursão em bis in idem, porquanto são arbitrados por ocasião da prolação da sentença nos autos da ação principal” (STJ, REsp 909.567/SP).

${ }^{20}$ Art. 475-F. Na liquidação por artigos, observar-se-á, no que couber, o procedimento comum (art. 272).
} 
Revista Eletrônica de Direito Processual - REDP. Volume 16. Julho a dezembro de 2015

Periódico Semestral da Pós-Graduação Stricto Sensu em Direito Processual da UERJ

Patrono: José Carlos Barbosa Moreira. ISSN 1982-7636. pp. 605-639 http://www.e-publicacoes.uerj.br/index.php/redp/index

necessidade de provar fato novo, ainda que para tanto seja necessária a produção de prova pericial, observar-se-á a liquidação por artigos.

Apesar de não ter o condão de rediscutir ou de alterar o resultado (e limites) da lide anterior (art. 509, $\S 4^{\circ}$ ), tendo natureza acessória (já que somente existirá se houver ação judicial anterior que crie título judicial sem determinação), em certos casos detém autonomia de alta escala. Isso porque determinados títulos judiciais necessitam de alta participação da liquidação de sentença por artigos para o detalhamento da condenação, uma vez que os calibramentos indenizatórios são estranhos à própria decisão que dará ensejo à liquidação, como ocorre no caso de sentença penal condenatória (art. 515, inc. VI ${ }^{21}$ ).

\subsection{1-Natureza jurídica.}

A liquidação por artigos apesar de não ter o condão de rediscutir ou de alterar o resultado (e limites) da lide anterior, tendo natureza acessória (já que somente existirá se houver ação judicial anterior que crie título judicial sem determinação), em certos casos detém autonomia de alta escala.

Vale lembrar que, na liquidação por artigos, a determinação do título depende da aferição de "fato novo" (fato secundário e dependente do que já foi decidido), reclamando dados muito acima dos já constantes nos autos. Esta situação nos faz concluir que a liquidação por artigos não poderá ser vista como simples incidente, mantendo, pois, natureza de ação. A assertiva é reforçada pela indicação legal de que a liquidação por artigos deve seguir o disposto no Livro I da Parte Especial do CPC/15 (art. 511)22.

\subsection{2 - Petição.}

\footnotetext{
${ }^{21}$ Art. 515. São títulos executivos judiciais, cujo cumprimento dar-se-á de acordo com os artigos previstos neste Título: (...) VI - a sentença penal condenatória transitada em julgado;

${ }^{22}$ Art. 511. Na liquidação pelo procedimento comum, o juiz determinará a intimação do requerido, na pessoa de seu advogado ou da sociedade de advogados a que estiver vinculado, para, querendo, apresentar contestação no prazo de 15 (quinze) dias, observando-se, a seguir, no que couber, o disposto no Livro I da Parte Especial deste Código.
} 
Revista Eletrônica de Direito Processual - REDP. Volume 16. Julho a dezembro de 2015

Periódico Semestral da Pós-Graduação Stricto Sensu em Direito Processual da UERJ

Patrono: José Carlos Barbosa Moreira. ISSN 1982-7636. pp. 605-639 http://www.e-publicacoes.uerj.br/index.php/redp/index

Ocorrendo caso concreto que reclame liquidação por artigos, deverá o postulante apresentar peça processual apontando de forma clara os elementos que dão supedâneo ao seu pedido de determinação do título judicial, com as justificativas da necessidade de alegação e comprovação dos "fatos novos".

É inegável que o ato que inaugura a liquidação por artigos reveste-se de aspecto formal vinculado ao art. $319^{23}$, com suas devidas adaptações, porquanto suas alegações devem propiciar ao antagônico a apresentação de defesa e, posteriormente, a fixação de pontos controversos pelo julgador, cuja finalidade é delimitar os meandros da dilação probatória.

\subsection{3-Intimação (citação) na pessoa do advogado.}

Consta no dispositivo comentado que a contraparte do liquidante será intimada, na pessoa de seu advogado ou da sociedade de advogados a que estiver vinculado advogado. Como se trata de convocação para responder ação secundária, o ato deve ser tratado como citação. A seguir a inteligência de outros casos parelhos ${ }^{24}$, a convocação processual em voga pode ser perfeitamente efetuada por imprensa, não se exigindo nem mesmo que advogado tenha poderes especiais para receber citação.

\subsection{4 - Decisão.}

A decisão final trabalhará com as alegações das partes e o material obtido, fixando-se os contornos da indenização, com a formação de coisa julgada material. Em relação ao

\footnotetext{
${ }^{23}$ Art. 319. A petição inicial indicará: I - o juízo a que é dirigida; II - os nomes, os prenomes, o estado civil, a existência de união estável, a profissão, o número de inscrição no Cadastro de Pessoas Físicas ou no Cadastro Nacional da Pessoa Jurídica, o endereço eletrônico, o domicílio e a residência do autor e do réu; III - o fato e os fundamentos jurídicos do pedido; IV - o pedido com as suas especificações; V - o valor da causa; VI - as provas com que o autor pretende demonstrar a verdade dos fatos alegados; VII - a opção do autor pela realização ou não de audiência de conciliação ou de mediação. $\S 1^{\circ}$ Caso não disponha das informações previstas no inciso II, poderá o autor, na petição inicial, requerer ao juiz diligências necessárias a sua obtenção. $\S 2^{\circ}$ A petição inicial não será indeferida se, a despeito da falta de informações a que se refere o inciso II, for possível a citação do réu. $\S 3^{\circ} \mathrm{A}$ petição inicial não será indeferida pelo não atendimento ao disposto no inciso II deste artigo se a obtenção de tais informações tornar impossível ou excessivamente oneroso o acesso à justiça.

${ }^{24}$ No sentido: "LIQUIDAÇÃO POR ARBITRAMENTO. CITAÇÃO DO RÉU NA PESSOA DO ADVOGADO, PELA IMPRENSA. ADMISSIBILIDADE. - Nos termos do disposto no art. 603, parágrafo único, do CPC, introduzido pela Lei n ${ }^{\circ} 8.898$, de 29.6.1994, a citação do réu far-se-á na pessoa de seu advogado constituído nos autos, mediante a publicação pela imprensa. Precedentes do STJ. Recurso especial não conhecido" (STJ, REsp. 259.608/SP).
} 
Revista Eletrônica de Direito Processual - REDP. Volume 16. Julho a dezembro de 2015

Periódico Semestral da Pós-Graduação Stricto Sensu em Direito Processual da UERJ

Patrono: José Carlos Barbosa Moreira. ISSN 1982-7636. pp. 605-639 http://www.e-publicacoes.uerj.br/index.php/redp/index

recurso, este será o de agravo de instrumento (art. 1.015, parágrafo único ${ }^{25}$ ), confira os comentários no item 10.

\subsection{5- Honorários.}

Assumindo feição de ação judicial, ainda que com suas peculiaridades, devem ser fixados honorários de advogado, notadamente se na liquidação por artigos houver litigiosidade ${ }^{26}$.

\section{3-Apuração por simples cálculo.}

Consoante já cravado em comentário acima (acerca das espécies de liquidação previstas no $\mathrm{CPC} / 15)$, em se tratando de apuração do valor que depende apenas de cálculo aritmético, não haverá liquidação de sentença propriamente dita. Em tais casos o credor (ou o devedor, diante da extensão de dupla legitimidade contida no caput do art. 509 - vide comentário no item número 06) poderá promover o cumprimento da sentença, atualizando o valor da condenação com programa de atualização financeira a ser disponibilizado pelo Conselho Nacional de Justiça ( $§ 3^{\circ}$ do art. 509).

Note-se que, segundo orientação fixada no próprio CPC/15 (art. 786, parágrafo único ${ }^{27}$ ), a necessidade de simples operações aritméticas para apurar o crédito exequendo não retira a liquidez da obrigação constante do título. $O$ uso de programa a ser disponibilizado pelo Conselho Nacional de Justiça único criará ambiente de isonomia e estabilidade, pois não são incomuns as discussões sobre as fórmulas dos programas de atualização que, como não há na lei a previsão de um vetor único, têm sido usados a partir de cardápio variante nos Tribunais pelo Brasil.

\footnotetext{
${ }^{25}$ Art. 1.015. Parágrafo único. Também caberá agravo de instrumento contra decisões interlocutórias proferidas na fase de liquidação de sentença ou de cumprimento de sentença, no processo de execução e no processo de inventário.

${ }^{26}$ Confira-se: "É cabível a fixação de honorários advocatícios em fase de liquidação por artigos quando esta assume caráter contencioso" (STJ, AgRg no Ag 1086058/SP).

${ }^{27}$ Art. 786. A execução pode ser instaurada caso o devedor não satisfaça a obrigação certa, líquida e exigível consubstanciada em título executivo. Parágrafo único. A necessidade de simples operações aritméticas para apurar o crédito exequendo não retira a liquidez da obrigação constante do título.
} 
Revista Eletrônica de Direito Processual - REDP. Volume 16. Julho a dezembro de 2015

Periódico Semestral da Pós-Graduação Stricto Sensu em Direito Processual da UERJ

Patrono: José Carlos Barbosa Moreira. ISSN 1982-7636. pp. 605-639 http://www.e-publicacoes.uerj.br/index.php/redp/index

Merece realçar que haverá a projeção do $\S 3^{\circ}$ do art. 509 para as discussões de excesso de execução por divergência de cálculo. Com efeito, nada obstante a sua posição topográfica estar fincada na parte de liquidação de sentença, o $\S 3^{\circ}$ do art. 509 tem aplicação em outras situações, notadamente quando o devedor discordar do valor apresentado pelo credor na memória de cálculo. Tal postura pode ser observada nos $\S \S 4^{\circ}$ e $5^{\circ}$ do art. $525^{28}$ (impugnação ao cumprimento de sentença), no art. $526^{29}$ (cumprimento espontâneo), no $\S 2^{\circ}$ do art. 535 (impugnação pela Fazenda Pública) ${ }^{30}$ e nos $\S \S 3^{\circ}$ e $4^{\circ}$ do art. $917^{31}$ (embargos à execução). Isso porque o $\S 3^{\circ}$ do art. 509 tem o escopo de fixar um critério único de atualização que, caso não aplicável, criará a necessidade de ser esclarecido o motivo da sua exclusão no caso concreto (p. exemplo, atualização de dívidas fiscais que seguem critérios peculiares).

\section{2-Liquidação de sentença nos casos de obrigação de fazer, não fazer e de entrega} de coisa.

O art. 509 apenas indica a liquidação quando a sentença não determinar o valor devido, não aduzindo acerca da obrigação de fazer, não fazer ou de entrega de coisa. O problema não é novo, pois estava contido no CPC/73 desde a Lei 11.232/05, ao revogar o art. 603, que previa a liquidação de sentença não apenas para se determinar o valor, mas também para "individuar o objeto da condenação".

\footnotetext{
${ }^{28}$ Art. 525 (...) $\S 4^{\circ}$ Quando o executado alegar que o exequente, em excesso de execução, pleiteia quantia superior à resultante da sentença, cumprir-lhe-á declarar de imediato o valor que entende correto, apresentando demonstrativo discriminado e atualizado de seu cálculo. $\S 5^{\circ} \mathrm{Na}$ hipótese do $\S 4^{\circ}$, não apontado o valor correto ou não apresentado o demonstrativo, a impugnação será liminarmente rejeitada, se o excesso de execução for o seu único fundamento, ou, se houver outro, a impugnação será processada, mas o juiz não examinará a alegação de excesso de execução.

${ }^{29}$ Art. 526. É lícito ao réu, antes de ser intimado para o cumprimento da sentença, comparecer em juízo e oferecer em pagamento o valor que entender devido, apresentando memória discriminada do cálculo.

${ }^{30}$ Art. $535(\ldots) \S 2^{\circ}$ Quando se alegar que o exequente, em excesso de execução, pleiteia quantia superior à resultante do título, cumprirá à executada declarar de imediato o valor que entende correto, sob pena de não conhecimento da arguição.

${ }^{31}$ Art. 917 (...) $\S 3^{\circ}$ Quando alegar que o exequente, em excesso de execução, pleiteia quantia superior à do título, o embargante declarará na petição inicial o valor que entende correto, apresentando demonstrativo discriminado e atualizado de seu cálculo. $\S 4^{\circ}$ Não apontado o valor correto ou não apresentado o demonstrativo, os embargos à execução: I - serão liminarmente rejeitados, sem resolução de mérito, se o excesso de execução for o seu único fundamento; II - serão processados, se houver outro fundamento, mas o juiz não examinará a alegação de excesso de execução.
} 
Revista Eletrônica de Direito Processual - REDP. Volume 16. Julho a dezembro de 2015

Periódico Semestral da Pós-Graduação Stricto Sensu em Direito Processual da UERJ

Patrono: José Carlos Barbosa Moreira. ISSN 1982-7636. pp. 605-639 http://www.e-publicacoes.uerj.br/index.php/redp/index

A omissão não impede, na nossa visão, que a liquidação para individuar o objeto da condenação possa ser implementada, devendo se adaptar às regras de liquidação por arbitramento e artigos para tanto. Pensar inverso, com todo respeito, importa em criar uma situação irreal de que todas as ações de obrigação de fazer, não fazer e de entrega de coisa terão pedido certo, a propiciar decisões com delimitação perfeita. Basta lembrar que, com tal raciocínio, nas ações universais, em que não se pode individuar os bens, não será possível a liquidação de sentença. Portanto, é perfeitamente admissível que se faça liquidação de sentença para individuar o objeto da condenação, em situações que a sentença genérica não delimitar, com todos os contornos referentes às obrigações de fazer, não fazer ou de entrega de coisa.

\section{3-Manutenção da impossibilidade de liquidação de título executivo extrajudicial.}

No CPC/15 não foi introduzida qualquer alteração que autorizasse a liquidação (por arbitramento ou por artigos) dos títulos executivos extrajudiciais. Assim, parece mantida a tradição em nosso sistema de limitar o espectro da liquidação de sentença aos títulos executivos judiciais, eis que:

(a) não consta no trecho dos arts. 509-512 qualquer indicativo de aplicação nos títulos executivos extrajudiciais;

(b) a conjugação dos art. 783-784 reclama que conste obrigação líquida no corpo do título executivo extrajudicial.

Há espaço, contudo, para uma reflexão acerca da correção de tal diretriz, pois a vedação de liquidação de títulos extrajudiciais poderá implicar em uso de via processual capilar, com objetivo parelho à própria liquidação. Por exemplo, o termo de ajustamento de conduta (título extrajudicial - art. $5^{\circ}, \S 6^{\circ}$, da LAP) é muitas vezes palco de obrigações que, embora certas, não trazem consigo a liquidez. Diante da carência de liquidação específica para tal título, é provável que a obrigação nele contida tenha que ser liquidada em ambiente 
Revista Eletrônica de Direito Processual - REDP. Volume 16. Julho a dezembro de 2015

Periódico Semestral da Pós-Graduação Stricto Sensu em Direito Processual da UERJ

Patrono: José Carlos Barbosa Moreira. ISSN 1982-7636. pp. 605-639

http://www.e-publicacoes.uerj.br/index.php/redp/index

alternativo, fazendo adaptações, como é o caso da produção antecipada de prova (art. 381 ${ }^{32}$ ),

muito embora o objetivo esteja mais afeto à medida de aperfeiçoamento dos arts. 509-512.

\section{4-Liquidação de sentença no âmbito do processo trabalhista ${ }^{33}$}

Diante do disposto no art. 15 do $\mathrm{CPC} / 15^{34}$, que faz alusão à aplicação da nova codificação ao processo do trabalho (além do processo administrativo e eleitoral) naquilo que for omisso e compativel ${ }^{35}$, há de ser abordada a liquidação de sentença em tal ambiente especial, confrontando a CLT com o diploma codificado aqui comentado.

Com efeito, o art. 879 da CLT $^{36}$ prevê que a liquidação de sentença no processo do trabalho poderá ser feita, a partir da peculiaridade do caso, por três formas distintas: (a)

${ }^{32}$ Art. 381. A produção antecipada da prova será admitida nos casos em que: I - haja fundado receio de que venha a tornar-se impossível ou muito difícil a verificação de certos fatos na pendência da ação; II - a prova a ser produzida seja suscetível de viabilizar a autocomposição ou outro meio adequado de solução de conflito; III - o prévio conhecimento dos fatos possa justificar ou evitar o ajuizamento de ação. $\S 1^{\circ} \mathrm{O}$ arrolamento de bens observará o disposto nesta Seção quando tiver por finalidade apenas a realização de documentação e não a prática de atos de apreensão. $\S 2^{\circ} \mathrm{A}$ produção antecipada da prova é da competência do juízo do foro onde esta deva ser produzida ou do foro de domicílio do réu. $\S 3^{\circ}$ A produção antecipada da prova não previne a competência do juízo para a ação que venha a ser proposta. $\S 4^{\circ} \mathrm{O}$ juízo estadual tem competência para produção antecipada de prova requerida em face da União, de entidade autárquica ou de empresa pública federal se, na localidade, não houver vara federal. $\S 5^{\circ}$ Aplica-se o disposto nesta Seção àquele que pretender justificar a existência de algum fato ou relação jurídica para simples documento e sem caráter contencioso, que exporá, em petição circunstanciada, a sua intenção.

${ }^{33} \mathrm{O}$ tema foi tratado com mais vagar no seguinte texto: MAZZEI, Rodrigo; GONÇALVES, Figueiredo Tiago. Liquidação de sentença (individual e coletiva): seus aspectos nucleares no processo comum e do trabalho. Revista Eletrônica - Tribunal Regional do Trabalho do Paraná, v. 3, p. 103-129, 2014.

${ }^{34}$ Art. 15. Na ausência de normas que regulem processos eleitorais, trabalhistas ou administrativos, as disposições deste Código lhes serão aplicadas supletiva e subsidiariamente.

${ }^{35}$ Embora sem a perfeita técnica, o art. 15 do $\mathrm{CPC} / 15$ ao se referir à aplicação supletiva e subsidiária aos processos eleitorais, trabalhistas ou administrativos, indica que a codificação será usada para preenchimento residual, ou seja, apenas nos campos omissos dos ambientes processuais de natureza especial e, ainda assim, somente quando as regras codificadas forem afinadas à principiologia das respectivas legislações. Com outras palavras, não basta a simples omissão ("ausência de normas") para a aplicação do CPC/15 nos espaços não preenchidos pela legislação especial, mister ainda se faz que o regramento importado seja compatível com o ambiente legal que o agasalha. Caso a solução do $\mathrm{CPC} / 15$ não seja adequada a principiologia da legislação especial não será possível a projeção da regra, devendo se buscar no sistema, numa visão ampla, outra solução, mais próxima às características desenhadas na legislação especial. Há, pois, o que chamamos de aplicação residual do Código de Processo Civil, fenômeno que já é perfeitamente vislumbrado na aplicação das regras processuais codificadas no microssistema da tutela coletiva. No tema, sendo possível adaptar as noções fixadas para o processo do trabalho, confira-se: MAZZEI, Rodrigo. A ação popular e o microssistema da tutela coletiva. Revista Forense, 2007, v. 394, p. 263-280; de forma mais sintética e direta: MAZZEI, Rodrigo. Da aplicação (apenas) 'residual' do CPC nas ações coletivas. MPMG Jurídico, v. 1, p. 37, 2006.

${ }^{36}$ Art. 879 - Sendo ilíquida a sentença exeqüenda, ordenar-se-á, previamente, a sua liquidação, que poderá ser feita por cálculo, por arbitramento ou por artigos. $\S 1^{\circ}$ - Na liquidação, não se poderá modificar, ou inovar, a sentença liquidanda nem discutir matéria pertinente à causa principal.§ 1--A. A liquidação abrangerá, também, o cálculo das contribuições previdenciárias devidas. § 1ㅇ-B. As partes deverão ser previamente intimadas para 
Revista Eletrônica de Direito Processual - REDP. Volume 16. Julho a dezembro de 2015

Periódico Semestral da Pós-Graduação Stricto Sensu em Direito Processual da UERJ

Patrono: José Carlos Barbosa Moreira. ISSN 1982-7636. pp. 605-639 http://www.e-publicacoes.uerj.br/index.php/redp/index

cálculo, (b) arbitramento e (c) artigos. Há particularidades que fazem com que a absorção do CPC/15 não seja total, aplicando-se em alguns pontos o princípio da especialidade.

Em relação à liquidação por cálculo (extinta no bojo do Novo CPC), tal medida deve ser recepcionada com reservas, pois no âmago do processo do trabalho, os cálculos podem tomar complexidade maior que uma simples conta aritmética (ou seja, aquela capaz de ser feita sem ajuda de profissional habilitado - em regra contador).

As liquidações por cálculo trabalhistas, muitas das vezes, acabam tendo alcance amplo, pois açambarcam não apenas as questões que antes eram controvertidas e foram sedimentadas no título executivo, mas também os seus 'reflexos', como é o caso das férias, décimo terceiro salário, horas extras, repouso semanal remunerado, contribuições previdenciárias $\left(\S 1^{\circ}-\mathrm{A}\right.$ e $\S 1^{\circ}-\mathrm{B}$, do art. 879 da CLT). Isso sem contar que haverá hipóteses outras em que a própria base de cálculo para os 'reflexos ' poderá necessitar de apresentação de uma conta mais complexa, como ocorre, por exemplo, no caso de incorporação de comissões no salário do trabalhador. Por tal passo, não é invulgar que as liquidações por cálculo no processo do trabalho acabem por desaguar ou mesmo iniciar na contadoria do juízo (= órgão auxiliar da Justiça do Trabalho - $\S 3^{\circ}$ do art. 879 da CLT) que, portanto, pode elaborar uma terceira conta (além da apresentada pelo credor e o devedor) ou até mesmo apresentar uma conta inaugural, abrindo a fase liquidatória. Em suma, apresentada a conta (seja por qualquer dos interessados ou pelo contador do Juízo) e colhido o contraditório, haverá um valor que será considerado como correto pelo juiz e que será alvo de homologação, em desdobramento do $\S 2^{\circ}$ do art. 879 da CLT.

\footnotetext{
a apresentação do cálculo de liquidação, inclusive da contribuição previdenciária incidente. $\S 2^{\circ}$ - Elaborada a conta e tornada líquida, o Juiz poderá abrir às partes prazo sucessivo de 10 (dez) dias para impugnação fundamentada com a indicação dos itens e valores objeto da discordância, sob pena de preclusão. $\S$ 3 - Elaborada a conta pela parte ou pelos órgãos auxiliares da Justiça do Trabalho, o juiz procederá à intimação da União para manifestação, no prazo de 10 (dez) dias, sob pena de preclusão. § 4ํㅜ A atualização do crédito devido à Previdência Social observará os critérios estabelecidos na legislação previdenciária. § 5ㅇ O Ministro de Estado da Fazenda poderá, mediante ato fundamentado, dispensar a manifestação da União quando o valor total das verbas que integram o salário-de-contribuição, na forma do art. 28 da Lei $n^{\circ} 8.212$, de 24 de julho de 1991, ocasionar perda de escala decorrente da atuação do órgão jurídico. § 6o Tratando-se de cálculos de liquidação complexos, o juiz poderá nomear perito para a elaboração e fixará, depois da conclusão do trabalho, o valor dos respectivos honorários com observância, entre outros, dos critérios de razoabilidade e proporcionalidade.
} 
Revista Eletrônica de Direito Processual - REDP. Volume 16. Julho a dezembro de 2015

Periódico Semestral da Pós-Graduação Stricto Sensu em Direito Processual da UERJ

Patrono: José Carlos Barbosa Moreira. ISSN 1982-7636. pp. 605-639 http://www.e-publicacoes.uerj.br/index.php/redp/index

Percebe-se que a trilha do art. $509, \S \S 2^{\circ}$ e $3^{\circ}$ do $\mathrm{CPC} / 15$ poderá não ser seguida no

âmbito de processos do trabalho, pois os cálculos possuem natureza liquidatória e a cognição deflagrada acaba tendo caráter complementar ao título e não simplesmente uma atualização de valor como se projeta na codificação processual civil.

No que se refere à liquidação de sentença por arbitramento, o caput do artigo 879 da CLT prevê tal possibilidade no processo do trabalho, não fazendo ao longo do dispositivo regulações que se afastem de forma clara do modelo do CPC/15. Semelhante ao que ocorre na liquidação por arbitramento, a CLT abarca a possibilidade da liquidação por artigos, mas não desenha qualquer diferencial ao que está regulado no $\mathrm{CPC} / 15$, aplicando-se tais regramentos no processo trabalhista com os devidos ajustes (artigo 769 da CLT $^{37}$ ). Vale, contudo, registrar que a demonstração de "fato novo" que dá origem à liquidação por artigos está blindada dos mesmos zelos do processo comum, em especial em relação ao princípio da fidelidade ( $\S 4^{\circ}$ do art. 509 do CPC), que também está consagrado no artigo $879, \S 1^{\circ}$, da CLT.

Em registro final, mesmo que em resenha, embora o $\S 6^{\circ}$ do art. 879 da CLT permita a nomeação de expert para apuração de cálculos de liquidação complexos, tal fato parece estar fora da liquidação por cálculos (ainda que com alguma complexidade), sendo aplicável apenas a liquidação por arbitramento e por artigos. No sentido, vale notar que o art. 789-A, inciso IX, da $\mathrm{CLT}^{38}$ prevê que o trabalho do contador do juízo - na realização de cálculos para a liquidação - deverá ser pago, ao final, pelo executado, sendo tratada a verba como custas judiciais (seguindo tabelamento, inclusive). Tal situação é diversa da hipótese de nomeação de perito ( $\left(6^{\circ}\right.$ do art. 879 da CLT), que ocorre nas liquidações por arbitramento e por artigos, em que há fixação de honorários (com observância a critérios de razoabilidade e proporcionalidade).

\footnotetext{
${ }^{37}$ Art. 769 - Nos casos omissos, o direito processual comum será fonte subsidiária do direito processual do trabalho, exceto naquilo em que for incompatível com as normas deste Título.

${ }^{38}$ Art. 789-A. No processo de execução são devidas custas, sempre de responsabilidade do executado e pagas ao final, de conformidade com a seguinte tabela: (...)IX - cálculos de liquidação realizados pelo contador do juízo - sobre o valor liquidado: 0,5\% (cinco décimos por cento) até o limite de $\mathrm{R} \$ 638,46$ (seiscentos e trinta e oito reais e quarenta e seis centavos)
} 
Revista Eletrônica de Direito Processual - REDP. Volume 16. Julho a dezembro de 2015

Periódico Semestral da Pós-Graduação Stricto Sensu em Direito Processual da UERJ

Patrono: José Carlos Barbosa Moreira. ISSN 1982-7636. pp. 605-639 http://www.e-publicacoes.uerj.br/index.php/redp/index

\section{5- Liquidação no processo coletivo ${ }^{39}$}

$\mathrm{O}$ CPC/15 não traz qualquer menção à liquidação coletiva, ou seja, àquela com o tecido no Código de Defesa do Consumidor (em especial arts. 95-97). Note-se que, como não há no sistema legal um código específico aos processos coletivos, formou-se à margem do CPC um microssistema da tutela coletiva, representado pelo conjunto de diplomas que tratam do assunto. Pelo maior espectro de aplicação e também pelo disposto nos artigos 90 e 117 da nossa legislação consumerista, a doutrina de escol normalmente faz tal aferição pela interação entre o Código de Defesa do Consumidor (CDC) e a Lei n. 7.347/85 (LACP).

Afirmamos, no entanto, que visão mais ampla há de ser empregada, pois, apesar de o CDC e a LACP terem, de fato, um status de relevância maior decorrente da natural constatação de possuírem âmbito de incidência de grande escala, os demais diplomas que formam o microssistema da tutela de massa têm também sua importância para o direito processual coletivo, implantando a inteligência de suas regras naquilo que for útil e pertinente, pois estão interligados, o que propicia a comunicação constante entre todas a normas do microssistema. ${ }^{40}$

Com tal norte estão compreendidas no microssistema as disposições que tratam do processo coletivo e que estão localizadas na Lei de Ação Popular (Lei 4117/65), na Lei dos Portadores de Deficiências (Lei 7.853/89), no Estatuto da Criança e do Adolescente (Lei 8.069/90), na Lei de Improbidade Administrativa (Lei 8.429/92), na Lei da Ordem Econômica (Lei 8.884/94), no Estatuto do Idoso (Lei 10.741/03), entre outros diplomas que possuem como base as disposições contidas na Constituição Federal, na Lei de Ação Civil Pública (Lei 7.347/85), e no Código de Defesa do Consumidor (Lei 8.078/90). ${ }^{41}$

O registro lançado (existência de microssistema coletivo, composto de normas múltiplas com comunicação) é muito relevante, dado que permite demonstrar que o CPC

\footnotetext{
${ }^{39}$ No tema, de forma mais aguda, confira-se: MAZZEI, Rodrigo; GONÇALVES, Figueiredo Tiago. Linhas básicas acerca da liquidação de sentença coletiva. Revista Brasileira de Direito Processual (RBDPro), v. 87, p. 70-95, 2014.

${ }^{40}$ MAZZEI, Rodrigo. A ação popular e o microssistema da tutela coletiva. Revista Forense, 2007, v. 394, p. 263-280.

${ }^{41}$ No sentido (entre vários): STJ, REsp 695.396/RS; REsp 510.150/MA.
} 
Revista Eletrônica de Direito Processual - REDP. Volume 16. Julho a dezembro de 2015

Periódico Semestral da Pós-Graduação Stricto Sensu em Direito Processual da UERJ

Patrono: José Carlos Barbosa Moreira. ISSN 1982-7636. pp. 605-639 http://www.e-publicacoes.uerj.br/index.php/redp/index

somente pode ser invocado de forma residual. Ainda que sutil a diferença (aplicação residual e não subsidiária), a questão deve ser realçada, evitando embaraços. Com efeito, o CPC - como norma de índole individual - somente será aplicado nos diplomas de caráter coletivo de forma residual. Assim, havendo omissão específica a determinada norma, não se adentrará - de imediato - em pesquisa para as soluções legais previstas no CPC, pois o intérprete deverá, antecedentemente, aferir se há paradigma legal dentro do conjunto de normas processuais do microssistema coletivo. Não basta, contudo, aplicar o CPC nos processos coletivos de forma residual. Deve ocorrer, ainda, a adaptação da norma individual do CPC (em homenagem ao princípio da adaptabilidade) aos reclames da demanda em que se debate 'interesses coletivos', uma vez que terá que se importar norma com concepção de processo não coletivo. ${ }^{42}{ }_{-}^{43}$

Postas as premissas básicas, a liquidação coletiva constitui-se numa liquidação especial, bastando se analisar o trecho dos artigos 95-100 do CDC. A liquidação proposta individualmente por cada uma das vítimas, a partir de uma decisão genérica coletiva, escapa à regra geral das liquidações regidas pelas normas do processo clássico, pelo que visa não só à comprovação do quantum debeatur, como, outrossim, à comprovação do dano - an debeatur - individualmente sofrido, como ainda à comprovação de ser, a possível vítima, afetada pelo dano abstratamente afirmado na sentença genérica - nexo de causalidade. Por isso que, nesse caso, a liquidação visa a não só reconhecer o quantum debeatur, como, também, o dano individual e o nexo causal com o dano geral. É natural que essa liquidação, diante de tamanha complexidade que a envolve, seja realizada - em regra - por artigos. É veemente a necessidade de que se faça prova de fatos novos. Desenvolve-se pela técnica do processo autônomo de liquidação, na medida em que cada titular de direito individual homogêneo deverá, de posse da sentença coletiva, promover a respectiva ação de liquidação.

Em relação à competência para conhecer da demanda liquidatória coletiva, a partir do disposto no art. $98, \S 2^{\circ}, \mathrm{I}, \mathrm{c} / \mathrm{c}$ art. 101, I, ambos do CDC, depreende-se esta não só do juízo que proferiu a sentença genérica liquidanda, como, outrossim, a competência do foro do

\footnotetext{
${ }^{42}$ Confira-se: MAZZEI, Rodrigo. A ação popular e o microssistema da tutela coletiva. Revista Forense, 2007, v. 394, p. 263-280; de forma mais sintética e direta: MAZZEI, Rodrigo. Da aplicação (apenas) 'residual' do CPC nas ações coletivas. MPMG Jurídico, v. 1, p. 37, 2006.

${ }^{43}$ Aplicando a noção de microssistema da tutela coletiva que defendemos: STJ, REsp 1.108.542/SC. Confirase ainda (entre vários): STJ, REsp. 1.217.554/SP.
} 
Revista Eletrônica de Direito Processual - REDP. Volume 16. Julho a dezembro de 2015

Periódico Semestral da Pós-Graduação Stricto Sensu em Direito Processual da UERJ

Patrono: José Carlos Barbosa Moreira. ISSN 1982-7636. pp. 605-639 http://www.e-publicacoes.uerj.br/index.php/redp/index

domicílio do liquidante. A par da liquidação e da consequente execução individual promovida por cada titular de direito subjetivo inserido na categoria dos direitos individuais homogêneos, a obrigação contida na sentença coletiva genérica na qual reconhecida a existência dos direitos individuais homogêneos pode ser objeto de liquidação e posterior execução coletiva. Esta possibilidade é aberta depois de decorrido um ano, contado do trânsito em julgado da decisão coletiva pela qual são tutelados direitos individuais homogêneos, sem que tenha havido a habilitação de legitimados individuais em número compatível com a dimensão e a gravidade do dano. A legitimidade para a promoção desta liquidação coletiva é conferida àqueles entes enumerados no art. 82 do $\mathrm{CDC}$ e no art. $5^{\circ}$ da LACP (vide, no sentido, a segunda parte do texto do art. 97 do CDC).

A liquidação coletiva seguida da execução coletiva conduz à obtenção de valor, o qual seria inicialmente dos titulares dos direitos individuais, e que é recuperado e revertido para o Fundo de Defesa dos Direitos Difusos - FDD (art. 13 da Lei 7347/85 e art. 100, parágrafo único, do $\mathrm{CDC}$ ), com o que se tem por afirmado e observado o princípio da tutela integral no âmbito coletivo. O valor assim recuperado é denominado de fluid recovery (recuperação ou reparação fluída).

Outrossim, a liquidação coletiva do direito difuso ou coletivo estrito senso é promovida por um dos legitimados enumerados no art. 82 do CDC e no art. $5^{\circ}$ da Lei 7347/85. Desenvolve-se pela técnica da liquidação fase, dando-se prosseguimento ao processo coletivo já pendente, no bojo do qual proferida a decisão que contém a obrigação a ser liquidada. Admite realização tanto pela modalidade por arbitramento quanto por artigos. A competência para a liquidação de obrigação imposta por sentença genérica proferida em demanda pela qual tutelado direito coletivo estrito senso ou direito difuso é do juízo que proferiu a sentença condenatória liquidanda.

Não se pode olvidar de que, em atenção ao fenômeno do transporte in utilibus (CDC art. $103, \S 3^{\circ}$ ), o titular de direito individual fica autorizado a se apropriar da decisão de procedência proferida em processo no qual reconhecido direito difuso ou coletivo estrito senso, mediante a propositura de ação de liquidação individual com a qual busca a 
Revista Eletrônica de Direito Processual - REDP. Volume 16. Julho a dezembro de 2015

Periódico Semestral da Pós-Graduação Stricto Sensu em Direito Processual da UERJ

Patrono: José Carlos Barbosa Moreira. ISSN 1982-7636. pp. 605-639 http://www.e-publicacoes.uerj.br/index.php/redp/index

individualização e a quantificação de seu direito. Nesse caso, a liquidação se desenvolve pela técnica do processo de liquidação e observa a modalidade por artigos.

$\mathrm{O}$ CPC/15 não altera o quadro acima traçado e mantém a célula individual da liquidação de sentença. De toda sorte, merece ser destacado o $\S 1^{\circ}$ do artigo 113 do CPC/15 - embora não seja um dispositivo de aplicação voltado exclusivamente para a liquidação de sentença - prevê a possibilidade de limitação de litisconsórcio facultativo nas liquidações de sentença quando o número de litigante puder comprometer a rápida solução do litígio ou dificultar a defesa ou até mesmo o cumprimento da sentença. O dispositivo trata de situação de pode ocorrer em liquidações coletivas com grande número de postulantes, notadamente em hipótese de direitos individuais homogêneos, sendo, assim, aplicável às ações coletivas.

\section{6-Legitimidade}

Pela arquitetura do $\mathrm{CPC} / 15$, a liquidação de sentença poderá ser requerida tanto pelo credor, quando pelo devedor, prestigiando, assim, a ideia da "ação liberatória" (que era extraída sem esforço do ventre do artigo 570 do Código de Processo Civil - revogado pela Lei 11.232/2005). A novidade é positiva, pois ratifica a concepção de que o cumprimento da decisão judicial, ainda que ilíquida, deve ser feita de forma espontânea pelo devedor, tendo pois este, para tanto, a legitimidade para promover a liquidação de sentença, assim como para o cumprimento do decisium de forma espontânea (art. 526).

\section{1-Limitação de litisconsórcio em liquidação de sentença.}

O juiz poderá limitar o litisconsórcio facultativo quanto ao número de litigantes na liquidação de sentença, quando este comprometer a rápida solução do litígio ou dificultar o trâmite normal do processo, notadamente com prejuízo a defesa. Tal controle está previsto de forma expressa no art. $113, \S 1^{\mathrm{o}}{ }^{44} \mathrm{e}$, a nosso ver, terá boa aplicação das liquidações de sentença coletivas.

\footnotetext{
${ }^{44}$ Art. $113(\ldots) \S 1^{\circ} \mathrm{O}$ juiz poderá limitar o litisconsórcio facultativo quanto ao número de litigantes na fase de conhecimento, na liquidação de sentença ou na execução, quando este comprometer a rápida solução do litígio ou dificultar a defesa ou o cumprimento da sentença.
} 
Revista Eletrônica de Direito Processual - REDP. Volume 16. Julho a dezembro de 2015

Periódico Semestral da Pós-Graduação Stricto Sensu em Direito Processual da UERJ

Patrono: José Carlos Barbosa Moreira. ISSN 1982-7636. pp. 605-639 http://www.e-publicacoes.uerj.br/index.php/redp/index

\section{7- Possibilidade da liquidação de sentença e cumprimento de sentença} simultâneo.

Caso a decisão possuir parte líquida e outra ilíquida, ao interessado é lícito promover simultaneamente a execução daquela e, em autos apartados, a liquidação desta (art. 509, § $\left.1^{\circ}\right)$

A solução legal é adequada e prestigia a concepção de duração razoável do processo diretriz constitucional (art. $5^{\circ}$. LXXVIII) que está recepcionada pelo $\mathrm{CPC} / 15$ de forma explícita $\left(\operatorname{arts} 4^{\circ}\right.$ e $\left.6^{\text {o45 }}\right)$.

Observe-se que a questão já estava tratada no revogado artigo 475-A, § $2^{\circ}$, mas pode receber algum colorido novo, com o "julgamento parcial de mérito", pois a decisão que julgar parcialmente o mérito poderá reconhecer a existência de obrigação líquida ou ilíquida simultaneamente. Em tais condições, a parte poderá liquidar ou executar, desde logo, a obrigação reconhecida na decisão que julgar parcialmente o mérito, independentemente de caução, ainda que haja recurso interposto, conforme previsto no art. 356 (e seus respectivos parágrafos $)^{46}$.

\section{8- Princípio da fidelidade e a Súmula 344 do STJ.}

O CPC/15 prestigia, no $\S 4^{\circ}$ do art. 509, o princípio da fidelidade, pois não é permitido que em sede de liquidação (qualquer que seja a modalidade) se discuta novamente a lide, sendo, outrossim, vedado modificar a decisão que a julgou. Todavia, tal diretriz não se

\footnotetext{
${ }^{45}$ Art. $4^{\circ}$ As partes têm o direito de obter em prazo razoável a solução integral do mérito, incluída a atividade satisfativa. Art. $6^{\circ}$ Todos os sujeitos do processo devem cooperar entre si para que se obtenha, em tempo razoável, decisão de mérito justa e efetiva.

${ }^{46}$ Art. 356. O juiz decidirá parcialmente o mérito quando um ou mais dos pedidos formulados ou parcela deles: I - mostrar-se incontroverso; II - estiver em condições de imediato julgamento, nos termos do art. $355 . \S 1^{\circ} \mathrm{A}$ decisão que julgar parcialmente o mérito poderá reconhecer a existência de obrigação líquida ou ilíquida. § $2^{\circ}$ A parte poderá liquidar ou executar, desde logo, a obrigação reconhecida na decisão que julgar parcialmente o mérito, independentemente de caução, ainda que haja recurso contra essa interposto. $\S 3^{\circ} \mathrm{Na}$ hipótese do $\S 2^{\circ}$, se houver trânsito em julgado da decisão, a execução será definitiva. $\S 4^{\circ}$ A liquidação e o cumprimento da decisão que julgar parcialmente o mérito poderão ser processados em autos suplementares, a requerimento da parte ou a critério do juiz. $\S 5^{\circ} \mathrm{A}$ decisão proferida com base neste artigo é impugnável por agravo de instrumento
} 
Revista Eletrônica de Direito Processual - REDP. Volume 16. Julho a dezembro de 2015

Periódico Semestral da Pós-Graduação Stricto Sensu em Direito Processual da UERJ

Patrono: José Carlos Barbosa Moreira. ISSN 1982-7636. pp. 605-639

http://www.e-publicacoes.uerj.br/index.php/redp/index

confunde com o entendimento firmado na Súmula 344 do STJ que dita que a opção por liquidação por forma diversa da estabelecida na sentença não ofende a coisa julgada.

Há sutil diferença, pois a coisa julgada só é, de fato, afrontada quando há a rediscussão da matéria de mérito objeto da fase cognitiva anterior ou a modificação da sentença liquidanda (princípio de fidelidade ao título). Isso porque a liquidação limita-se à quantificação do valor exequendo, em consonância com os critérios estabelecidos na sentença.

Diferente, pois, da situação prevista na Súmula 344 do STJ, que se fixa na possibilidade, a partir do caso concreto, de se permutar a forma de liquidação, ao se verificar que a forma liquidanda que foi fixada na sentença não é adequada para a perfeita quantificação do quantum. Basta pensar numa situação em que o juiz fixou que a liquidação deveria se dar por arbitramento, mas, diante da verificação de que será necessário fazer prova de fato novo, a liquidação mais adequada ao caso é a por artigos ${ }^{47}$. A troca da forma de liquidação não afetará a obrigação a ser liquidada, pois há vedação para discutir de novo a lide ou modificar a decisão respectiva, mas tão somente definirá o mais adequado trilho processual da liquidação. Com tal norte, tem-se admitido também que é possível se dispensar na fase executiva a liquidação determinada em sentença, caso se verifique que se trata de questão que pode ser resolvida por simples conta aritmética ${ }^{48}$.

\section{1-Capítulos decisórios implícitos}

\footnotetext{
${ }^{47}$ No sentido: “A coisa julgada só é afrontada quando há a rediscussão da matéria de mérito objeto da fase cognitiva anterior ou a modificação da sentença liquidanda (princípio de fidelidade ao título), limitando-se a fase de liquidação, portanto, à quantificação do valor exequendo, em consonância com os critérios estabelecidos na sentença. Inteligência da Súmula 344 do STJ. (...) Ante a presunção de dados utilizada pelo perito judicial, denota-se que o procedimento liquidatório mais adequado à espécie não é a liquidação por arbitramento, visto ser imprescindível a prova de fato novo - o número de coletas em que transportados valores e o real montante desses valores -, o que aponta para a necessidade da liquidação por artigos" (STJ, REsp. 1.234.765/RS).

48 No sentido: "Jurisprudência pacífica desta Corte no sentido de ser desnecessário o procedimento de liquidação quando o valor da condenação depender apenas de cálculos aritméticos” (STJ, STJ, REsp 1232569/PB).
} 
Revista Eletrônica de Direito Processual - REDP. Volume 16. Julho a dezembro de 2015

Periódico Semestral da Pós-Graduação Stricto Sensu em Direito Processual da UERJ

Patrono: José Carlos Barbosa Moreira. ISSN 1982-7636. pp. 605-639 http://www.e-publicacoes.uerj.br/index.php/redp/index

Também não viola o princípio da fidelidade a inclusão em liquidação de sentença de determinadas questões, tais como correção monetária ${ }^{49}{ }^{50}$ e os juros de mora, consoante pode se extrair da inteligência da Súmulas 254 do $\mathrm{STF}^{51}$. Todavia, tal não se aplica com toda extensão a todos pedidos implícitos, pois os honorários, embora previstos como tal (art. 322), por entendimento da Súmula 453 do STJ estão vedados de inclusão na fase de liquidação, caso não tenha a decisão liquidanda os previstos expressamente.

De toda sorte, há posição diversa, admitindo a inclusão dos honorários em fase de liquidação ou execução, muito embora sem decisão a respeito, por entender se tratar de 'erro material'. Tal entendimento foi extratizado no Enunciado n. 8 do Fórum Permanente dos Processualistas Civis (FPPC). ${ }^{52}$

\section{9- Alegação de fatos impeditivos, modificativos ou extintivos.}

A jurisprudência tem entendido que os fatos impeditivos, modificativos ou extintivos ocorridos após proferida a decisão (que contém a obrigação a ser liquidada) devem ser arguidos em sede de cumprimento de sentença, fora do ambiente da liquidação ${ }^{53}$, pois a última não se presta a examinar o juízo de valor, mas apenas de quantificação.

Tal posição há de ser recepcionada com muita cautela, pois fatos supervenientes à sentença, de natureza impeditiva, modificativa ou extintiva podem influenciar diretamente a fixação do valor apurado. A dinâmica de fatos, normalmente vinculadas à relação jurídica de trato continuado, pode gerar espaço para revisão da decisão (ainda que alcançada pela

\footnotetext{
${ }^{49}$ No sentido: STJ, REsp 256.704/RN.

${ }^{50}$ Importante destacar, contudo, que a inclusão da correção monetária, não pode ser equiparada a troca do seu critério, pois tal postura fere o princípio da fidelidade e deverá ser rechaçado, não se admitindo (STJ, Rcl 10.090/MT).

51 Súmula 254 STF: Incluem-se os juros moratórios na liquidação, embora omisso o pedido inicial ou a condenação.

${ }^{52}$ Enunciado 8 (arts. 85, $\S 18,494$, II, 1.022, III) Fica superado o enunciado 453 da súmula do STJ após a entrada em vigor do CPC.

${ }^{53}$ No sentido: "A liquidação por arbitramento se destina apenas à elaboração de perícia para apurar o crédito a ser executado, nas hipóteses em que ele não pode ser determinado mediante mero cálculo. Se há necessidade de prova de fatos novos, procede-se à liquidação por artigos. Mas a discussão de fatos impeditivos, modificativos ou extintivos do crédito deve sedar na impugnação de sentença, não na liquidação" (STJ, REsp 976.888/MG).
} 
Revista Eletrônica de Direito Processual - REDP. Volume 16. Julho a dezembro de 2015

Periódico Semestral da Pós-Graduação Stricto Sensu em Direito Processual da UERJ

Patrono: José Carlos Barbosa Moreira. ISSN 1982-7636. pp. 605-639 http://www.e-publicacoes.uerj.br/index.php/redp/index

coisa julgada), consoante autorizado pelo art. 505, $\mathrm{I}^{54}$, não sendo necessário impugnar o fato em sede cumprimento de sentença.

\section{0 - Recurso cabível.}

Segundo dicção expressa do parágrafo único do art. 1.015, caberá agravo de instrumento contra decisões interlocutórias proferidas na fase de liquidação de sentença. $\mathrm{O}$ dispositivo abre flanco para alguma dúvida, pois faz vinculação genérica às decisões interlocutórias proferidas em liquidação de sentença. Ora, é possível que estas sejam traduzidas como as decisões interlocutórias proferidas no curso da liquidação (ou seja, do início até a decisão final) ou com abrangência a todas as decisões em sede de liquidação (inclusive a que dá desfecho à liquidação, ou seja, a decisão final.).

O dispositivo do CPC/15 não repete a fórmula expressa do revogado art. 475-H, que afirmava que cabia agravo de instrumento da decisão da liquidação de sentença, pontuando, de forma óbvia, na decisão final. A dúvida pode surgir em relação à liquidação por artigos, diante da natureza de ação que esta possui (art. 511). De toda sorte, ao que parece, a ideia é que o agravo de instrumento seja a espécie recursal adequada para atacar qualquer decisão interlocutória proferida nas duas modalidades de liquidação, incluindo em seu espectro as decisões finais.

\section{1 - Liquidação na pendência do julgamento do recurso.}

$\mathrm{O}$ art. 509 do CPC/15 permite que a parte interessada (credor ou devedor) inicie a liquidação, adotando tal medida através de pedido no juízo de origem, instruindo sua postulação com as peças processuais pertinentes.

Da regra conclui-se que: (a) é irrelevante que o recurso tenha ou não efeito suspensivo; (b) necessita de pedido expresso (logo, não pode ser iniciada de ofício);

\footnotetext{
${ }^{54}$ Art. 505. Nenhum juiz decidirá novamente as questões já decididas relativas à mesma lide, salvo:I - se, tratando-se de relação jurídica de trato continuado, sobreveio modificação no estado de fato ou de direito, caso em que poderá a parte pedir a revisão do que foi estatuído na sentença; (...)
} 
Revista Eletrônica de Direito Processual - REDP. Volume 16. Julho a dezembro de 2015

Periódico Semestral da Pós-Graduação Stricto Sensu em Direito Processual da UERJ

Patrono: José Carlos Barbosa Moreira. ISSN 1982-7636. pp. 605-639 http://www.e-publicacoes.uerj.br/index.php/redp/index

(c) a parte deverá apresentar petição própria, observando a modalidade de liquidação;

(d) a petição será processada no juízo de origem; (e) há necessidade de instrução com as peças processuais que permitam a liquidação, não tendo o legislador previamente indicado um rol obrigatório.

\section{1 - Liquidação na pendência do julgamento do recurso não se confunde com 'execução provisória' (cumprimento provisório de sentença).}

O dispositivo comentado tem o objetivo de aproveitar o 'tempo morto' do processo, possibilitando o aperfeiçoamento da sentença enquanto pende o julgamento de impugnação recursal. Não pode ser confundida com cumprimento provisório de sentença (art. 517), pois a liquidação na pendência do julgamento do recurso, ainda que tenha um ponto de provisoriedade, já que fica na dependência do desfecho do processo, não implica em nenhum ato de constrição, ao contrário do cumprimento provisório de sentença. Assim, sequer pode se cogitar em caução ou qualquer tipo de medida próxima em relação ao pedido de liquidação na pendência do julgamento do recurso (ou, liquidação provisória). Na verdade, trata-se de ato processual que poderá preceder a execução provisória.

Com efeito, se o recurso possui efeito suspensivo, a liquidação poderá ser iniciada antes mesmo da eficácia concreta da decisão, caso contrário, se a postulação do recorrente não tiver efeito suspensivo, a liquidação precederá a execução provisória. Nas duas situações, fica facultado ao liquidante adiantar a liquidação da decisão, ainda que com o risco de ver seu trabalho não ser aproveitado, no caso de sucesso do recurso da parte antagônica, quando terá que se examinar os efeitos do resultado do julgamento recursal, observando o que efetivamente foi atingido pela decisão recursal.

\section{2- Decisão com capítulos líquidos e ilíquidos.}

A decomposição da sentença em capitulos permite a liquidação na pendência do julgamento do recurso, mormente se a decisão contiver capítulo(s) líquido(s) e também ilíquido(s). Isso porque é perfeitamente possível que seja proferida sentença contendo 
Revista Eletrônica de Direito Processual - REDP. Volume 16. Julho a dezembro de 2015

Periódico Semestral da Pós-Graduação Stricto Sensu em Direito Processual da UERJ

Patrono: José Carlos Barbosa Moreira. ISSN 1982-7636. pp. 605-639 http://www.e-publicacoes.uerj.br/index.php/redp/index

capítulo líquido (por exemplo, fixando o dano moral em quantia certa), mas também possuindo capítulo ilíquido (por exemplo, sobre dano material que se desconhece a extensão - art. 324, $\left.\S 1^{\circ}, I^{55}\right)$. Nessa situação, permite-se a depuração dos capítulos, vindo o credor a se utilizar do art. 512 apenas na parte ilíquida, combinando o dispositivo com o art. 509, § 1.

\section{3- Peças que devem instruir a liquidação provisória.}

Não há indicação das peças que devem instruir o pedido de liquidação na pendência do julgamento do recurso.

De toda sorte, é intuitivo, na falta de melhor delimitação na norma, a lembrança da regra contida no art. $522^{56}$ que traz rol de material documentado para o cumprimento provisório de sentença e autorização de autenticação das peças do processo pelo advogado da parte postulante. Para a demonstração da obrigação a ser liquidada, a priori, todo o material no sentido que estiver nos autos deve ser colacionado (por exemplo, contrato que indique a raiz da obrigação), além das peças processuais básicas para tanto: (a) decisão liquidanda; (b) certidão de interposição de recurso; (c) procurações outorgadas pelas partes.

\section{4- Conjugação com a hipoteca judiciária ${ }^{57}$.}

A liquidação provisória (art. 512) pode ser conjugada com a hipoteca judiciária, colocando o seu beneficiário da obrigação numa situação de privilégio. Basta lembrar que aquele que detém a seu favor uma sentença condenatória - ainda que ilíquida - pode

\footnotetext{
${ }^{55}$ Art. 324. O pedido deve ser determinado. § $1^{\circ}$ É lícito, porém, formular pedido genérico: (...) II - quando não for possível determinar, desde logo, as consequências do ato ou do fato;

${ }^{56}$ Art. 522. O cumprimento provisório da sentença será requerido por petição dirigida ao juízo competente. Parágrafo único. Não sendo eletrônicos os autos, a petição será acompanhada de cópias das seguintes peças do processo, cuja autenticidade poderá ser certificada pelo próprio advogado, sob sua responsabilidade pessoal: I - decisão exequenda; II - certidão de interposição do recurso não dotado de efeito suspensivo; III - procurações outorgadas pelas partes; IV - decisão de habilitação, se for o caso; V - facultativamente, outras peças processuais consideradas necessárias para demonstrar a existência do crédito.

${ }^{57}$ Sobre hipoteca judiciária no CPC/15, confira-se: MAZZEI, Rodrigo; SERPA, Lucas. Hipoteca judiciária: breves noções e sua nova roupagem (segundo o Projeto de Novo Código de Processo Civil). Revista Jurídica (Porto Alegre. 1953), v. 445, p. 37-60, 2014.
} 
Revista Eletrônica de Direito Processual - REDP. Volume 16. Julho a dezembro de 2015

Periódico Semestral da Pós-Graduação Stricto Sensu em Direito Processual da UERJ

Patrono: José Carlos Barbosa Moreira. ISSN 1982-7636. pp. 605-639 http://www.e-publicacoes.uerj.br/index.php/redp/index

perfeitamente constituir hipoteca judiciária incidente sobre o patrimônio do seu devedor (art. $495^{58}$ ), pouco importando que o recurso tenha efeito suspensivo (art. $495, \S 1^{\text {o }}$, inciso III).

Em relação à constituição da hipoteca judiciária vale lembrar que, além de admissível em decisões ilíquidas, a urgência não figura como requisito para sua formalização. Há que se ressaltar, todavia, que a hipoteca judiciária possui procedimento com viés essencialmente prático e célere, mas que tem grande repercussão na esfera patrimonial do responsável, podendo, ainda que involuntariamente, criar embaraços e violar princípios e garantias fundamentais como a ampla defesa e o contraditório.

Atento a essa problemática, o CPC tenta não deixar margens para qualquer dúvida e prevê que no prazo de até quinze dias da data da realização da hipoteca, a parte [beneficiada com a garantia propiciada com a formalização da hipoteca judiciária] deve informar o juízo, que, a seu turno, deverá intimar a outra parte para tomar ciência do ato $\left(\S 3^{\circ}\right.$ do art. 495). Entende-se que ao abrir vista para ciência do ato, deverá o juiz conceder prazo para que a parte vencida se manifeste, trazendo, nesse momento, eventuais questões que impossibilitam a inscrição hipotecária, tal como a alegação de impenhorabilidade do bem (em caso de bem de família, por exemplo).

Dessa forma, pode a parte formalizar primeiramente a hipoteca judiciária e, logo em sequência, depois de estabilizada a garantia, apresentar pedido de liquidação provisória, ou vice versa (e até com pedidos apresentados na mesma data), pois não há cadência processual rígida entre as duas figuras jurídicas em comento (hipoteca judiciária e liquidação provisória). Importante notar, conjunto que a simbiose entre os dois institutos permite que o

\footnotetext{
${ }^{58}$ Art. 495. A decisão que condenar o réu ao pagamento de prestação consistente em dinheiro e a que determinar a conversão de prestação de fazer, de não fazer ou de dar coisa em prestação pecuniária valerão como título constitutivo de hipoteca judiciária. $\S 1^{\circ} \mathrm{A}$ decisão produz a hipoteca judiciária: I - embora a condenação seja genérica; II - ainda que o credor possa promover o cumprimento provisório da sentença ou esteja pendente arresto sobre bem do devedor; III - mesmo que impugnada por recurso dotado de efeito suspensivo. $\S 2^{\circ} \mathrm{A}$ hipoteca judiciária poderá ser realizada mediante apresentação de cópia da sentença perante o cartório de registro imobiliário, independentemente de ordem judicial, de declaração expressa do juiz ou de demonstração de urgência. $\S 3^{\circ}$ No prazo de até 15 (quinze) dias da data de realização da hipoteca, a parte informá-la-á ao juízo da causa, que determinará a intimação da outra parte para que tome ciência do ato. § $4^{\circ} \mathrm{A}$ hipoteca judiciária, uma vez constituída, implicará, para o credor hipotecário, o direito de preferência, quanto ao pagamento, em relação a outros credores, observada a prioridade no registro. $\S 5^{\circ}$ Sobrevindo a reforma ou a invalidação da decisão que impôs o pagamento de quantia, a parte responderá, independentemente de culpa, pelos danos que a outra parte tiver sofrido em razão da constituição da garantia, devendo o valor da indenização ser liquidado e executado nos próprios autos.
} 
Revista Eletrônica de Direito Processual - REDP. Volume 16. Julho a dezembro de 2015

Periódico Semestral da Pós-Graduação Stricto Sensu em Direito Processual da UERJ

Patrono: José Carlos Barbosa Moreira. ISSN 1982-7636. pp. 605-639 http://www.e-publicacoes.uerj.br/index.php/redp/index

beneficiário de sentença ilíquida possa adiantar o (eventual) futuro cumprimento de sentença, criando ambiente mais seguro, diante dos efeitos da hipoteca judiciária que no CPC/15 inclui o direito de preferência (art. $495, \S 4^{\circ}$ ).

\section{2- Quadro Comparativo}

Em desfecho, cremos ser oportuno colacionar quadro comparativo, a fim de que os regramentos das codificações de 1973 e 2015 possam ser analisados conjuntamente, facilitando a verificação das principais mudanças, notadamente as indicadas no presente texto.

\begin{tabular}{|c|c|}
\hline 973 & CPC \\
\hline $\begin{array}{l}\text { Art. 475-A. Quando a sentença } \\
\text { não determinar o valor devido, procede- } \\
\text { se à sua liquidação. } \\
\S 10 \text { Do requerimento de } \\
\text { liquidação de sentença será a parte } \\
\text { intimada, na pessoa de seu advogado. } \\
\S 20 \text { A liquidação poderá ser } \\
\text { requerida na pendência de recurso, } \\
\text { processando-se em autos apartados, no } \\
\text { juízo de origem, cumprindo ao } \\
\text { liquidante instruir o pedido com cópias } \\
\text { das peças processuais pertinentes. } \\
\S \text { 3o Nos processos sob } \\
\text { procedimento comum sumário, } \\
\text { referidos no art. } 275 \text {, inciso II, alíneas } \\
\text { 'd' e 'e' desta Lei, é defesa a sentença } \\
\text { ilíquida, cumprindo ao juiz, se for o } \\
\text { caso, fixar de plano, a seu prudente } \\
\text { critério, o valor devido. }\end{array}$ & $\begin{array}{l}\text { Art. 509. Quando a sentença } \\
\text { condenar ao pagamento de quantia } \\
\text { ilíquida, proceder-se-á à sua liquidação, a } \\
\text { requerimento do credor ou do devedor: } \\
\text { I - por arbitramento, quando } \\
\text { determinado pela pentença, } \\
\text { convencionado pelas partes ou exigido } \\
\text { pela natureza do objeto da liquidação; } \\
\text { II - pelo procedimento comum, } \\
\text { quando houver necessidade de alegar e } \\
\text { provar fato novo. } \\
\S 1^{\circ} \text { Quando na sentença houver } \\
\text { uma parte líquida e outra ilíquida, ao } \\
\text { credor é lícito promover simultaneamente } \\
\text { a execução daquela e, em autos apartados, } \\
\text { a liquidação desta. } \\
\S 2^{\circ} \text { Quando a apuração do valor } \\
\text { depender apenas de cálculo aritmético, o }\end{array}$ \\
\hline
\end{tabular}


Revista Eletrônica de Direito Processual - REDP. Volume 16. Julho a dezembro de 2015

Periódico Semestral da Pós-Graduação Stricto Sensu em Direito Processual da UERJ

Patrono: José Carlos Barbosa Moreira. ISSN 1982-7636. pp. 605-639 http://www.e-publicacoes.uerj.br/index.php/redp/index

\begin{tabular}{|c|c|}
\hline $\begin{array}{l}\text { Art. } 475 \text {-B. Quando a } \\
\text { determinação do valor da condenação } \\
\text { depender apenas de cálculo aritmético, } \\
\text { o credor requererá o cumprimento da } \\
\text { sentença, na forma do art. 475-J desta } \\
\text { Lei, instruindo o pedido com a memória } \\
\text { discriminada e atualizada do cálculo. } \\
\text { Art. 475-C. Far-se-á a liquidação } \\
\text { por arbitramento quando: } \\
\text { I - determinado pela sentença ou } \\
\text { convencionado pelas partes; } \\
\text { II - o exigir a natureza do objeto } \\
\text { da liquidação. } \\
\text { Art. } 475 \text {-G. É defeso, na } \\
\text { liquidação, discutir de novo a lide ou } \\
\text { modificar a sentença que a julgou. } \\
475-I, \S 2^{\circ} \text {. Quando na sentença } \\
\text { houver uma parte líquida e outra } \\
\text { ilíquida, ao credor é lícito promover } \\
\text { simultaneamente a execução daquela e, } \\
\text { em autos apartados, a liquidação desta. }\end{array}$ & $\begin{array}{l}\text { credor poderá promover, desde logo, o } \\
\text { cumprimento da sentença. } \\
\qquad \$ 3^{\circ} \mathrm{O} \text { Conselho Nacional de Justiça } \\
\text { desenvolverá e colocará à disposição dos } \\
\text { interessados programa de atualização } \\
\text { financeira. } \\
\qquad \S 4^{\circ} \mathrm{Na} \text { liquidação é vedado discutir } \\
\text { de novo a lide ou modificar a sentença que } \\
\text { a julgou. }\end{array}$ \\
\hline
\end{tabular}


Revista Eletrônica de Direito Processual - REDP. Volume 16. Julho a dezembro de 2015

Periódico Semestral da Pós-Graduação Stricto Sensu em Direito Processual da UERJ

Patrono: José Carlos Barbosa Moreira. ISSN 1982-7636. pp. 605-639 http://www.e-publicacoes.uerj.br/index.php/redp/index

\begin{tabular}{|c|c|}
\hline $\begin{array}{l}\text { Art. 475-F. Na liquidação por } \\
\text { artigos, observar-se-á, no que couber, o } \\
\text { procedimento comum (art. 272). }\end{array}$ & $\begin{array}{l}\text { Art. 511. Na liquidação pelo } \\
\text { procedimento comum, o juiz determinará } \\
\text { a intimação do requerido, na pessoa de seu } \\
\text { advogado ou da sociedade de advogados a } \\
\text { que estiver vinculado, para, querendo, } \\
\text { apresentar contestação no prazo de } 15 \\
\text { (quinze) dias, observando-se, a seguir, no } \\
\text { que couber, o disposto no Livro I da Parte } \\
\text { Especial deste Código }\end{array}$ \\
\hline $\begin{array}{l}\text { Art. 475-A, } \S 2^{\circ} \text { - A liquidação } \\
\text { poderá ser requerida na pendência de } \\
\text { recurso, processando-se em autos } \\
\text { apartados, no juízo de origem, } \\
\text { cumprindo ao liquidante instruir o } \\
\text { pedido com cópias das peças } \\
\text { processuais pertinentes. }\end{array}$ & $\begin{array}{l}\text { Art. 512. A liquidação poderá ser } \\
\text { realizada na pendência de recurso, } \\
\text { processando-se em autos apartados no } \\
\text { juízo de origem, cumprindo ao liquidante } \\
\text { instruir o pedido com cópias das peças } \\
\text { processuais pertinentes. }\end{array}$ \\
\hline
\end{tabular}


Revista Eletrônica de Direito Processual - REDP. Volume 16. Julho a dezembro de 2015

Periódico Semestral da Pós-Graduação Stricto Sensu em Direito Processual da UERJ

Patrono: José Carlos Barbosa Moreira. ISSN 1982-7636. pp. 605-639 http://www.e-publicacoes.uerj.br/index.php/redp/index

\section{REFERÊNCIAS BIBLIOGRÁFICAS}

ALVIM NETTO, José Manoel de Arruda; et. al. Código do consumidor comentado. 2. ed. rev. e ampl. 2 tir. São Paulo: RT, 1995.

ARRUDA, Antônio Carlos Matteis de. Lineamentos para o esboço de uma teoria geral do processo de liquidação da sentença. A lide de liquidação. Dissertação de Mestrado sob orientação do Doutor José Manoel de Arruda Alvim Netto. São Paulo: PUC, 1979.

BOTELHO, Tiago Resende; FAVA, Gustavo Crestani. Da liquidação do direito em sentenças coletivas - class actions settlement: Revista Jurídica UNIGRAN, v. 15, n. 29. Dourados: UNIGRAN, 2013.

CARVALHO, Fabiano. Liquidação de sentença: determinação do cálculo aritmético, de acordo com a lei 11.232/2005. In HOFFMAN, Paulo; RIBEIRO, Leonardo Ferres da Silva (coords). Processo de Execução Civil: modificações da Lei 11.232/05, São Paulo: Quartier Latin, 2006.

DIDIER JR., Fredie. Fundamentos do Principio da Cooperação no Direito Processual Civil Português. Coimbra: Coimbra Editora, 2010.

DINAMARCO, Cândido Rangel. Execução civil. 5. ed. rev. atual e ampl. São Paulo: Malheiros, 1997. . Instituições de direito processual civil, vol. IV. São Paulo: Malheiros, 2004. . As três figuras de liquidação de sentença: Fundamentos do processo civil moderno, vol. II. 3. ed. São Paulo: Malheiros, 2000.

GONÇALVES, Tiago Figueiredo. A "liquidação" de obrigação imposta por sentença em demanda metaindividual: Processo civil coletivo. Coord.: Rodrigo Mazzei e Rita Dias Nolasco. São Paulo: Quartier Latin, 2005.

GRINOVER, Ada Pellegrini; et. al. Código brasileiro de defesa do consumidor. Forense: Rio de Janeiro, 1991.

LEITE, Carlos Henrique Bezerra. Liquidação na ação civil pública: o processo e a efetividade dos direitos humanos, enfoques civis e trabalhistas. São Paulo: LTR, 2004.

LIMA, Alcides de Mendonça. Comentários ao código de processo civil, vol 6, t. II. 2. ed. Forense: Rio de Janeiro, 1977.

MANCUSO, Rodolfo de Camargo. Manual do consumidor em juizo. 2. ed. rev. atual. e ampl. São Paulo: Saraiva, 1998. 
Revista Eletrônica de Direito Processual - REDP. Volume 16. Julho a dezembro de 2015

Periódico Semestral da Pós-Graduação Stricto Sensu em Direito Processual da UERJ

Patrono: José Carlos Barbosa Moreira. ISSN 1982-7636. pp. 605-639 http://www.e-publicacoes.uerj.br/index.php/redp/index

MARINONI, Luiz Guilherme. Mitidiero, Daniel. O Projeto do CPC: crítica e propostas.

São Paulo: Revista dos Tribunais, 2010.

MAZZEI, Rodrigo; Reforma do CPC: leis 11.187/2005, 11.232/2005, 11.276/2006, 11.277/2006 e 11.280/2006. São Paulo: RT, 2006.

Reforma do CPC 2: leis 11.383/2006 e 11.341/2006. São Paulo: RT, 2007.

. A liquidação por arbitramento e a liquidação por artigos: pontos relevantes sob a ótica das leis 11.232/05 e 11.382/06: Revista eletrônica de direito processual, vol. V. Ano 4. Rio de Janeiro, 2010.

. Da aplicação (apenas) "residual” do CPC nas ações coletivas. MPMG Jurídico, Belo Horizonte, v.1, n.3, p.37, dez., 2005/jan., 2006.

. Embargos de declaração e agravo interno no Projeto de CPC (Substitutivo de lavra do Deputado Paulo Teixeira): algumas sugestões para ratificações do texto projetado. Revista de Processo, v. 221, 2013.

. A ação popular e o microssistema da tutela coletiva. Ação popular - aspectos controvertidos e relevantes - 40 anos da Lei 4717/65. Coord.: Luiz Manoel Gomes Jr. e Ronaldo Fenelon Santos Filho São Paulo: RCS, 2006.

. A ação popular e o microssistema da tutela coletiva. Revista Forense, v. 394, p. 263-280, 2007.

. A ação popular e o microssistema da tutela coletiva. Tutela Jurisdicional Coletiva.

Coord.: Fredie Didier Jr. e José Henrique Mouta. Salvador: Juspodivm, 2009, v. 1, p. 373 395.

. A ação popular e o microssistema da tutela coletiva. Revista Jurídica da Faculdade de Direito da Universidade de Ribeirão Preto, v. 1, p. 221-244, 2011.

- A 'liquidação’ por cálculos após as (últimas) reformas (Leis 11.232/05e 11.382/06). In: Ernane Fidélis dos Santos; Luiz Rodrigues Wambier; Nelson Nery Jr.; Teresa Arruda Alvim Wambier. (Org.). Execução civil: estudos em homenagem ao Professor Humberto Theodoro Jr.. São Paulo: Revista dos Tribunais, 2007;

MAZZEI, Rodrigo; GONÇALVES, Figueiredo Tiago. Liquidação de sentença (individual e coletiva): seus aspectos nucleares no processo comum e do trabalho. Revista Eletrônica Tribunal Regional do Trabalho do Paraná, v. 3, 2014; 
Revista Eletrônica de Direito Processual - REDP. Volume 16. Julho a dezembro de 2015

Periódico Semestral da Pós-Graduação Stricto Sensu em Direito Processual da UERJ

Patrono: José Carlos Barbosa Moreira. ISSN 1982-7636. pp. 605-639 http://www.e-publicacoes.uerj.br/index.php/redp/index . Linhas básicas acerca da liquidação de sentença coletiva. Revista Brasileira de

Direito Processual (RBDPro), v. 87, 2014.

MAZZEI, Rodrigo; SERPA, Lucas. Hipoteca judiciária: breves noções e sua nova roupagem (segundo o Projeto de Novo Código de Processo Civil). Revista Jurídica (Porto Alegre. 1953), v. 445, 2014;

MOREIRA, José Carlos Barbosa. O novo processo civil brasileiro. 20. ed. rev. e atual. Rio de Janeiro: Forense, 1999.

NUNES, Dierle José Coelho. O princípio do contraditório: uma garantia de influência e não surpresa. In: DIDIER Jr., Fredie; JORDÃO, Eduardo Ferreira (Coords.). Teoria do processo: panorama doutrinário mundial. Salvador: JusPodivm, 2008.

OLIVEIRA, Carlos Alberto Álvaro de. Garantia do Contraditório. In: TUCCI, José Rogério Cruz e (Coord.). Garantias constitucionais do processo civil. São Paulo: Revista dos Tribunais, 1998.

PIZZOL, Patrícia Miranda. Liquidação nas ações coletivas. São Paulo: Lejus, 1998.

PONTES DE MIRANDA. Comentários ao código de processo civil, tomo IX (arts. 566611). Rio-São Paulo: Forense, 1976.

SILVA, Ovídio Baptista da. Curso de processo civil: execução obrigacional, execução real, ação mandamentais, vol. 2. 4. ed. rev. e atual. São Paulo: RT, 2000.

THEODORO JÚNIOR, Humberto. Processo de execução. 19 ed. São Paulo: Leud, 1999.

WAMBIER, Luiz Rodrigues. Sentença civil: liquidação e cumprimento. 3. ed. rev., atual. e ampl. São Paulo: RT, 2006.

WAMBIER, Luiz Rorigues; WAMBIER, Teresa Arruda Alvim. Anotações sobre a liquidação e a execução das sentenças coletivas: Direito processual coletivo e o anteprojeto de código brasileiro de processos coletivos. Coord.: Ada Pellegrini Grinover, Aluisio Gonçalves de Castro Mendes e Kazuo Watanabe. São Paulo: RT, 2007.

ZANETI JR., Hermes. Processo Constitucional: O Modelo Constitucional do Processo Civil Brasil

ZAVASCKI, Teori Albino. Comentários ao código de processo civil, vol 8: do processo de execução, arts. 566 a 645. São Paulo: RT, 2000. 